$30 / 481$ d\%

i) 30320

(25)

OR $0214=3$

NVO-311

\title{
CONTAINMENT AND SAFETY REVIEW FOR THE MIGHTY OAK NUCLEAR WEAPON EFFECTS TEST
}

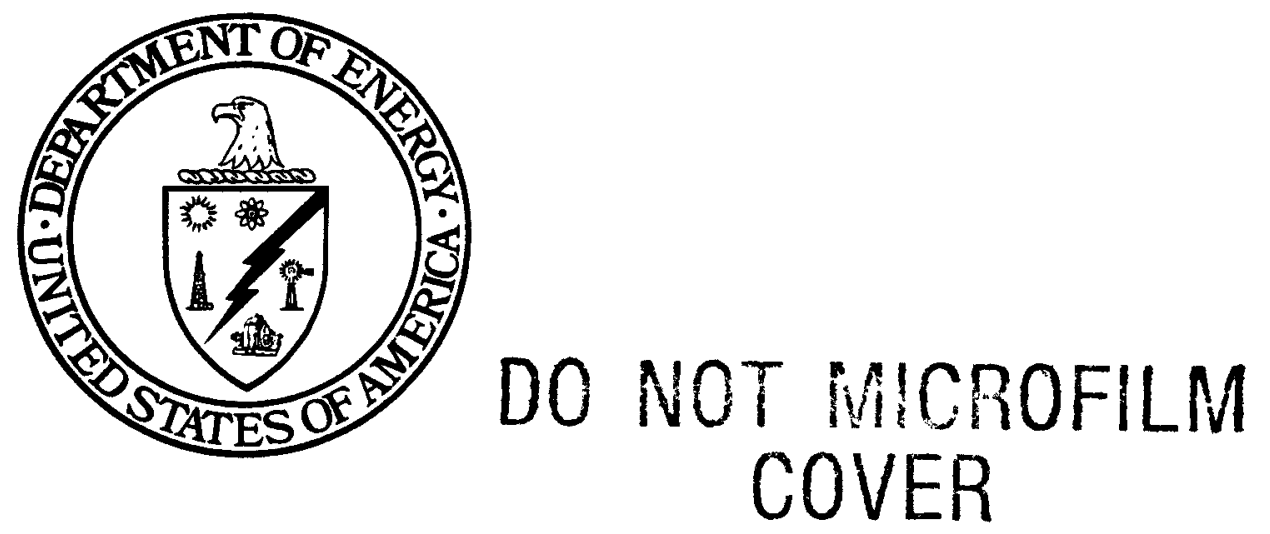

MAY 1, 1987 


\section{DO NOT MCROFILM ounin}

\section{DISCLAIMER}

This report was prepared as an account of work sponsored by the United States Government. Neither the United States Department of Energy, nor any of its employees, makes any warranty, express or implied, or assumes any legal liability or responsibility for the accuracy, completeness, or usefulness of any information, apparatus, product, or process disclosed, or represents that its use would not infringe privately owned rights. Reference herein to any specific commercial product, process, or service by trade name, mark, manufacturer, or otherwise, does not necessarily constitute or imply its endorsement, recommendation, or favoring by the United States Government or any agency thereof. The views and opinions of authors expressed herein do not necessarily state or reflect those of the United States Government or any agency thereof.

This report has been reproduced directly from the best available copy.

Available from the National Technical Information Service

U.S. Department of Commerce

Springfield, Virginia 22161

Price: Printed Copy $\mathrm{A03}$

Microfiche A01 


\section{DISCLAIMER}

This report was prepared as an account of work sponsored by an agency of the United States Government. Neither the United States Government nor any agency Thereof, nor any of their employees, makes any warranty, express or implied, or assumes any legal liability or responsibility for the accuracy, completeness, or usefulness of any information, apparatus, product, or process disclosed, or represents that its use would not infringe privately owned rights. Reference herein to any specific commercial product, process, or service by trade name, trademark, manufacturer, or otherwise does not necessarily constitute or imply its endorsement, recommendation, or favoring by the United States Government or any agency thereof. The views and opinions of authors expressed herein do not necessarily state or reflect those of the United States Government or any agency thereof. 


\section{DISCLAIMER}

Portions of this document may be illegible in electronic image products. Images are produced from the best available original document. 
NVO--311

NVO-311

DE87 008899

\author{
CONTAINMENT AND SAFETY ASSESSMENT \\ FOR THE \\ MIGHTY OAK \\ NUCLEAR WEAPON EFFECTS TEST
}

MAY 1, 1987

U.S. DEPARTMENT OF ENERGY
NEVADA OPERATIONS OFFICE

\title{
DISCLAIMER
}

This report was prepared as an account of work sponsored by an agency of the United States Government. Neither the United States Government nor any agency thereof, nor any of their employees, makes any warranty, express or implied, or assumes any legal liability or responsibility for the accuracy, completeness, or usefulness of any information, apparatus, product, or process disclosed, or represents that its use would not infringe privately owned rights. Reference herein to any specific commercial product, process, or service by trade name, trademark, manufacturer, or otherwise does not necessarily constitute or imply its endorsement, recommendation, or favoring by the United States Government or any agency thereof. The views and opinions of authors expressed herein do not necessarily state or reflect those of the United States Government or any agency thereof.

\section{MASTER}

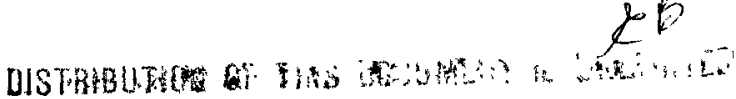

$$
\text { ili /iii }
$$




\section{FORENORD}

A nuclear weapon effects test named MIGHTY OAK was. conducted in tina $T$ tunnel complex of Rainier Mesa at the Nevada Test Site on April 10 , 1986.

This report has been prepared by the U.S. Department of Energy (DOE) and the Department. of Defense (DOD) to document the methods and controls associated with nuclear weapons tunnel tests in general and MIGSTY OAK in particular. All pretest and posttest operational procedures associazed with MIGHTY OAK were conducted in accordance with DoE and ivevada Operations office Directives, Orders, and Notices.

APPROVED BY:
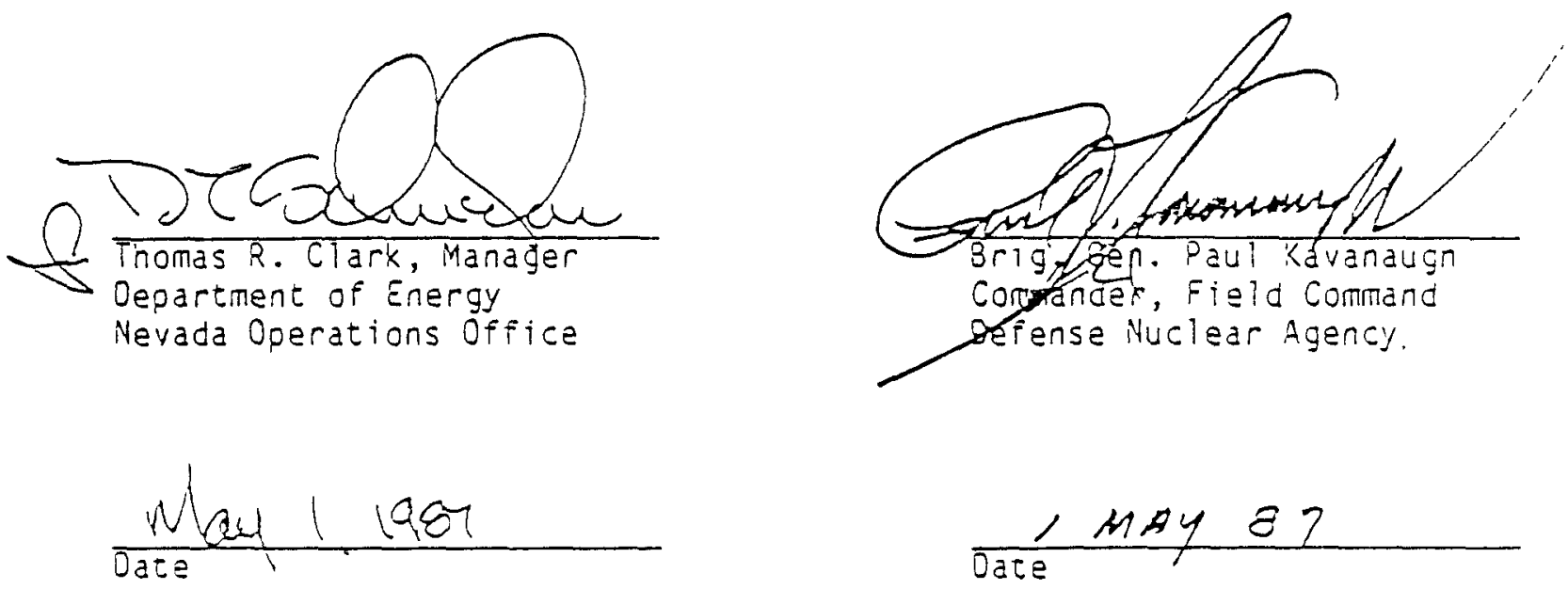
TABLE OF CONTENTS

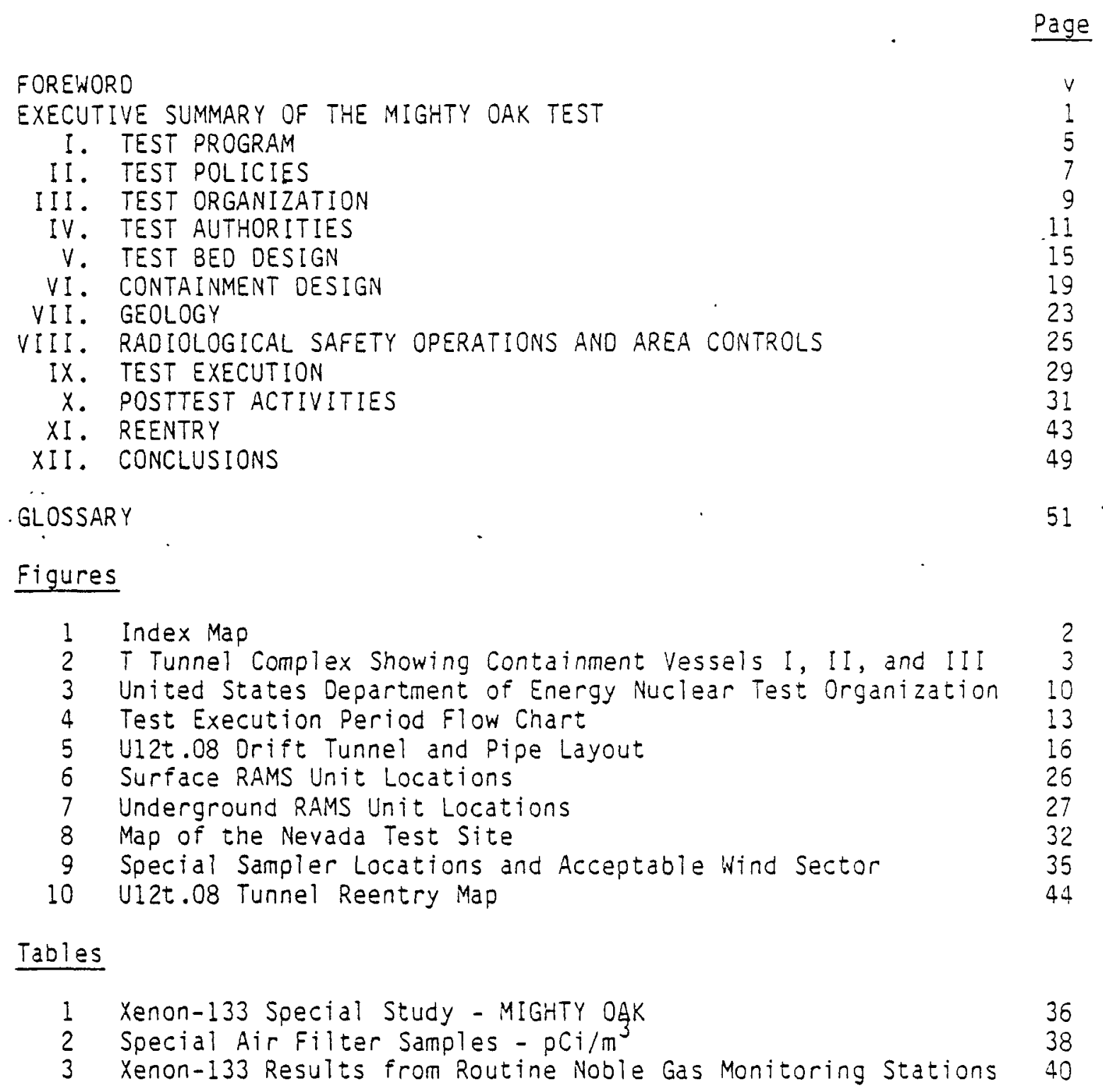

$$
\text { vi/vii }
$$




\section{EXECUTIVE SUMMARY OF THE MIGHTY OAK TEST}

On the morning of April 10, 1986, the U.S. Department of Energy (DOE) conducted a nuclear weapons effects test at the Nevada Test Site (NTS) (Figure 1) for the Defense Nuclear Agency (ONA) (an agent for cne Department of Defense). The test, MIGHTY OAK, was conducted 1,300 ieet below the surface of Rainier Mesa in the T tunnel complex (Figure 2).

MIGHTY OAX was a successful test from the perspectives of both the experiment data returned and containment. There are, however, two major issues related to the execution of the MIGHTY OAK test: the perceived lack of containment of radiation, and loss of equipment within the tunnel complex.

From the standpoint of containment, there was no accidental release of radioactivity to the atmosphere whatsoever. All radioactivity was contained within the tunnel complex until April 16 when the first controlled purging of the tunnel took place. Purging is a process wherein the alr within the tunnel complex is mechanically ventilated (pumped through filters) to the outside environment to remove noxious and possibly explosive gases. Such purging is carried out routinely following eacn tunnel test conducted at the NTS to facilitate safe reentry of personne? into the tunnel. MIGHTY OAK purging resulted in a known amount of radioactive noble gases being released in a controlled manner to the atmosphere (well within guidelines). The U.S. Environmental Protection Agency (IPA) prepared a report* that provides off-site radiological information gathered during purging operations. The maximum dose any person would have received standing in the open, downwind, for the entire period oi purging, would have been $0.27 \mathrm{microrem}$. This dose would have been equivalent to less than 1-1/2 minutes of extra exposure to natural background radiation at that same location.

From the standpoint of data recovery, MIGHTY OAK was successful. Approximately $85 \%$ of the data from prime test objectives was recovered; however, only $70 \%$ of the overall data was recovered. Most equipment--experiment, diagnostic, and construction--within the tunnel complex was lost. Tnis loss occurred as a result of high temperature and radiation. Other passive experiments and data were recovered. Loss of normally recoverable and reusable equipment was approximately 32 million dollars.

Underground testing is part of DOE's Research, Development, and Testing Program. As such, unanticipated outcomes are both expected and accepted. we learn from such experiences and use the results to go forward witn improved programs.

* "Off-site Monitoring for the MIGHTY OAK Nuclear Test," EPA 600/4-36-030, dated July 1986. 


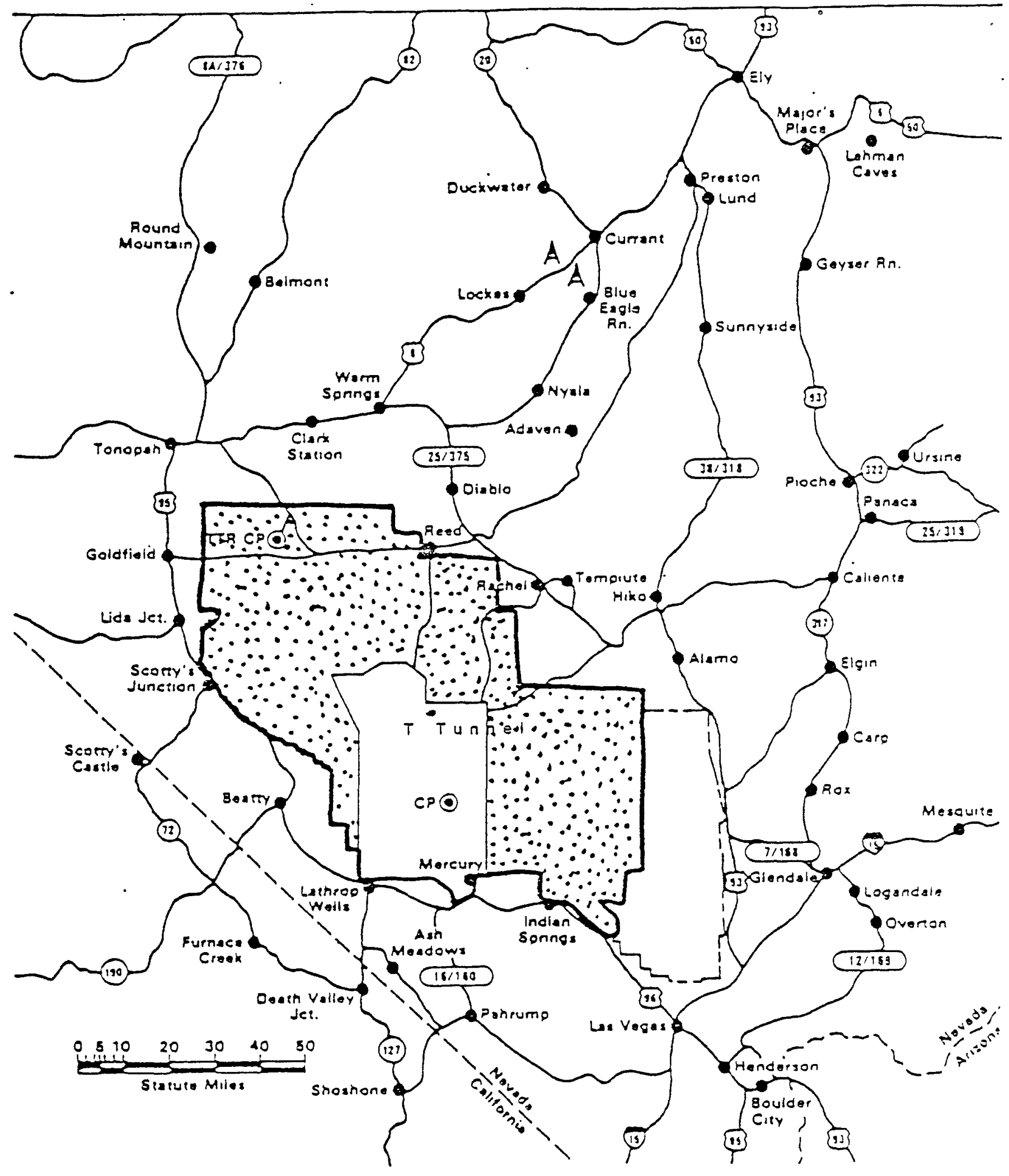

0 


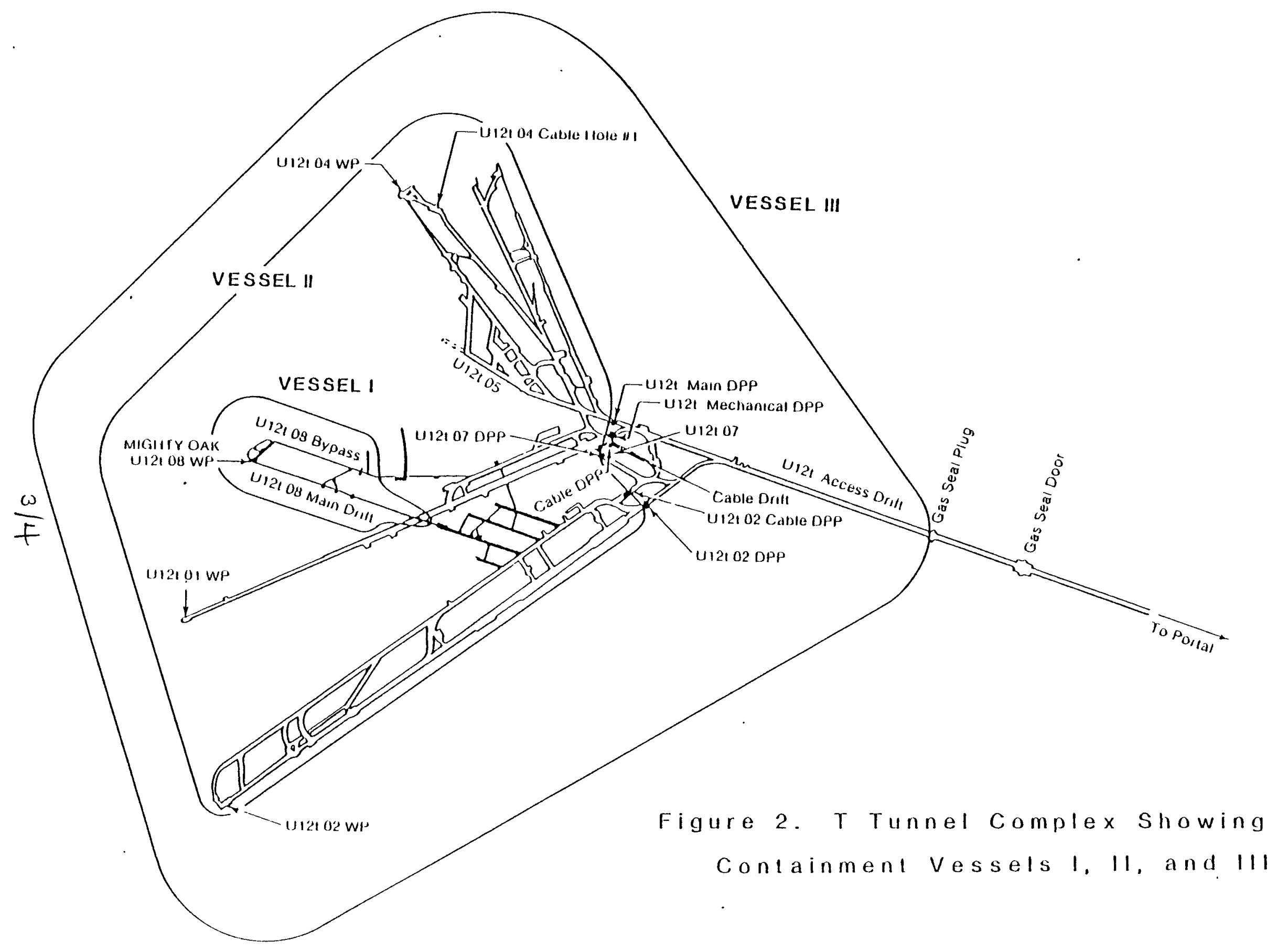


SECTION I

TEST PROGRAM

\section{Nevada Test Site}

The NTS*, located approximately 65 miles northwest of Las Vegas, is one of the world's largest research and development installations (Figure l). It occupies 1,350 square miles, an area larger than the state of Rhode Island. It is bounded on three sides by additional hundreds of thousands of acres belonging to the U.S. Nellis Air Force Base Range Complex. Because of its unique isolation, underground nuclear experiments can be conducted safely on the NTS.

President Truman chose the NTS as an on-continent testing ground in December 1950. The first nuclear test at the NTS was conducted a montn later on January 27,1951 . Nuclear testing continued at the NTS until 1958. It was then suspended because both the United States and the Soviet Union had voluntarily declared a moratorium. Nuclear testing resumed in 1961 when the Soviet Union broke the moratorium with a series of 31 tests--including the world's largest explosion (58 megatons)--during a 2month period.

Most of the early nuclear detonations at the NTS were conducted in tne atmosphere. Since 1962, all nuclear explosive tests (except for a few cratering experiments) have taken place hundreds or thousands of feet beneath the surface of the ground, either in sealed vertical shafts or horizontal tunnels. Thus, radioactive materials have, for the most part, been completely contained and kept out of the biosphere.

Purpose of Testing

The purpose of the nuclear weapons test program is to sustain the nation's defense capabilities. This objective is expressed in the Atomic Energy Act of 1946 (as amended in 1954), which states: "The development, use, and control of Atomic Energy shall be directed so as to make the maximum contribution to the general welfare, subject at all times to the paramoun: objective of making the maximum contribution to the common defense and security." Among other things, the Act authorizes the U.S. Atomic Energy Commission, now the DOE, to "conduct experiments and do research and development work in the military application of Atomic Energy." Such a research and development program requires the testing of new nuclear weapon designs and concepts.

*A glossary of acronyms used in this report begins on page 51 . 


\section{Testing Safety}

Advances in containment design have virtually eliminated earlier difficulties associated with accidental radioactive releases to the atmosphere from underground nuclear explosions. In fact, the last significant release was in December 1970. Even so, all tests are conducted with the assumption that an accidental release of radioactivity could occur. Accordingly, no test is conducted unless the safety of people both on and off the NTS can be assured, in the unlikely event a containment failure would occur. Data and information relating to safety concerns are provided by the EPA and the weather Service Nuclear Support office (WSNSO), an arm of the National weather Service.

In support of nuclear explosive testing, the EPA and its predecessor, the U.S. Public Health Service, have operated a routine radiation monitoring network within a 200-mile radius of the NTS since 1954. They have operated additional standby stations in every state west of the Mississippi River, except Alaska and Hawaii. The EPA can activate an independent monitoring network covering the entire U.S. if circumstances warrant. Also, EPA personnel are deployed in the downwind area during each and every test to document any release of radioactivity that may occur and to implement protective actions, if necessary.

WSNSO personnel collect and analyze meteorological data from the NTS and surrounding areas as well as from the National Meteorological Center in Washington, D.C. Using this data, meteorologists make local pretest weather forecasts. If winds are blowing toward populated areas where protective actions cannot be adequately taken, the test is postponed until favorable weather conditions exist. 
SECTION II

TEST POLICIES

The Manager of the OOE's Nevada Operations Office (NV) is responsibie for ensuring that each nuclear test is carried out in compliance witn che following DOE policies:

- Emplacement and firing of each nuclear device is to be conducted in a manner that conforms with United States obligations under the 1963 Limited Test Ban Treaty (LTBT) and the 1974 Threshold Test Ban Treaty (TTBT).

- All test operations are to be designed in a manner consistent with radiation guidelines published in oog Orders which, in turn, conform to national and international guidelines.

- Each test is to be designed to be successfully contained.

- Considerations of cost, schedules, and test objectives are not permitted to influence the review of the adequacy of safety features of any test. 
SECTION III

TEST ORGANIZATION

The NTS is operated by the DOE as an outdoor laboratory for the conduct of nuclear tests sponsored by Los Alamos National Laboratory (LANL), Lawrence Livermore National Laboratory (LLNL), Sandia National Laboratories (SNL), and the DNA.

The Manager, NV, is responsible for the safe conduct of each nuclear test, containment of radioactive debris underground, and posttest operations.

Each scientific laboratory or agency sponsoring a nuclear test is responsible to the Manager, NV, for the design of systems for nuclear device emplacement, stemming, and test execution. The test sponsors are given temporary control of specified areas (such as ground zero (GZ) areas) and are assigned primary responsibility for safety coordination within such areas.

Test operations are conducted within the framework of an organization known as the Nuclear Test Organization (NTO) (Figure 3). A DOE Test Controller (TC) appointed by the Manager, NV, is delegated full responsibility to head the NTO and to ensure safe conduct of each nuclear test. He is supported by a TC's Advisory Panel consisting of individuals having professional training and experience in fields of underground testing such as: phenomenology, meteorology, off-site environinental protection, radiation medicine, and other subjects pertaining to the safe conduct of the test. The chairman of the Panel is the Scientific Advisor nominated by the sponsoring laboratory and approved by the Manager, NV. In addition, a Test Group Director (TGO) is assigned by the sponsoring test organization to direct fielding and technical aspects of experiments and tests.

For the MIGHTY OAK test, the Scientific Advisor was furnished by SNL and the TGD was furnished by DNA. 


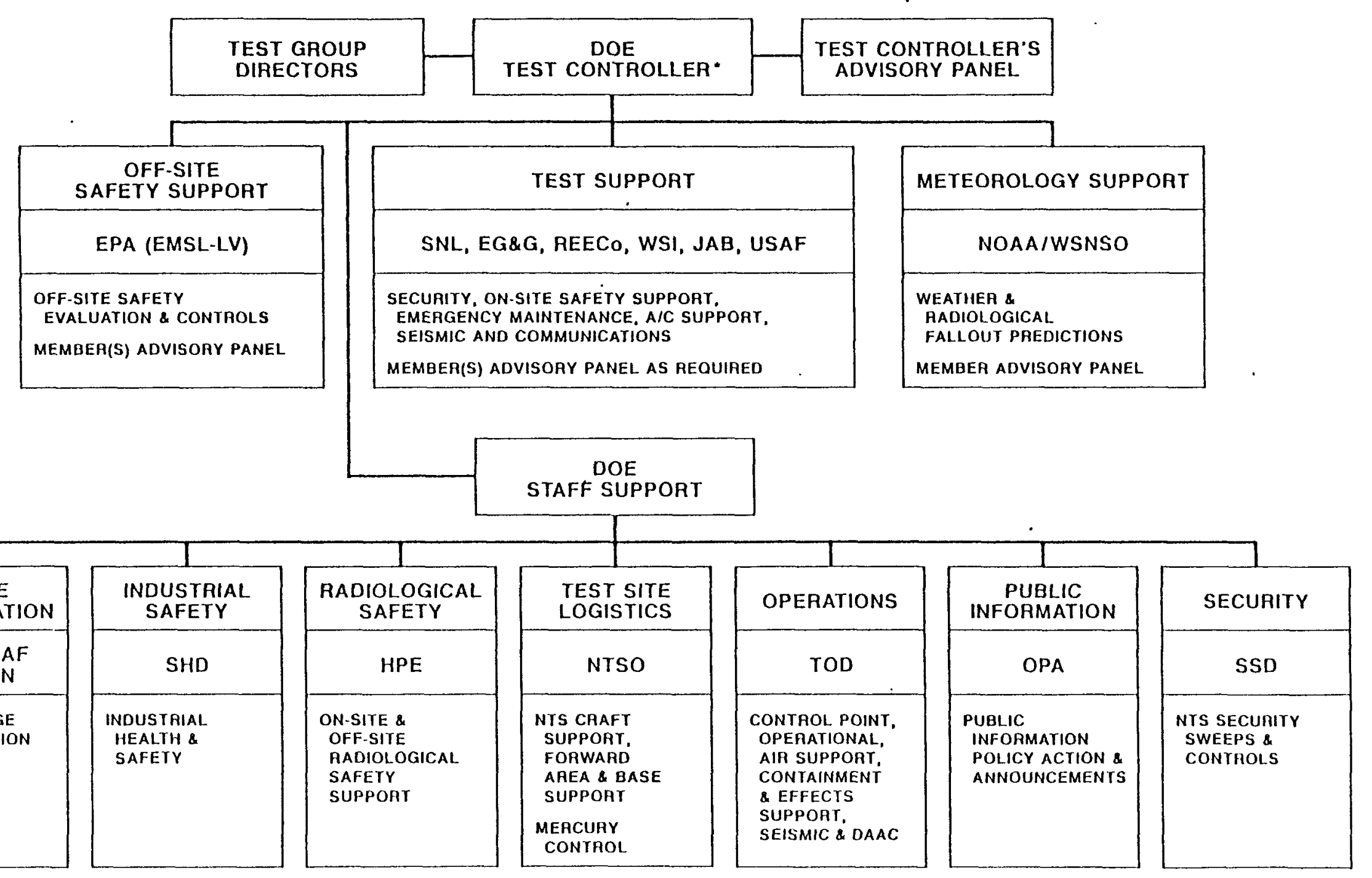

- oesignated uy tile manager. nv, fon eacil test on special experiment. (ASSUMES OPEIIATIONAL CONIHOL OF NIS DURHG TEST EXECUION PEIIIODS)

Figure 3. United Stales Department of Encrgy Nuclear Test Organization 


\section{SECTION IV \\ TEST AUTHORITIES}

Four basic authorities underlie nuclear tests at the NTS. They include Programmatic Authority; Detonation Authority; Authority to Move, Emplace, and Stem; and Permission to Fire. These authorities are discussed below.

\section{Programmatic}

Each year the Secretary of Energy proposes a program for the upcoming year in a letter to the President through the National Security Council (NSC). The NSC solicits formal comments on the proposed test program from its members and incorporates these comments in its recommendation letter to the President. Programmatic requests are approved annually and are signed by the President or his designee.

On September 30, 1985, President Reagan signed programmatic approval for the fiscal year 1986, CHARIOTEER series test program. This program included the MIGHTY OAK test.

Detonation Authority

Detonation authority is granted by the Director of Military Application, DOE, Headquarters, based on a Detonation Authority Request (DAR) package submitted by the Manager, NV. The DAR includes recommendations of the Containment Evaluation Panel (CEP); a report on the status of NV's approval of the nuclear explosive safety study/survey; a review of compliance with the TTBT; a review of environmental compliance; public announcement plans; programmatic authority status; and any particularly noteworthy aspects of the test.

After careful study and review of the request for detonation authority, the Director of Military Application at DOE Headquarters granted detonation authority on March 19, 1986, for the MIGHTY OAK event.

Permission to Move, Emplace, and Stem

A request for authority to move, emplace, and stem (backill the emplacement tunnel) a nuclear device originates with the sponsoring laboratory's TGD and is addressed to the TC assigned operational control for the specified event. If detonation authority has been received from the Director of Military Application, the TC will normally approve the request.

Permission to move, emplace, and stem for MIGHTY OAK was given by the DOE TC on March 21, 1986. 
Permission to fire

On the day before the scheduled detonation $(D-1)$, separate briefings are held on pertinent aspects of readiness. They include

1. details of containment and construction,

2. technical considerations, and

3. operational readiness (weather, operations, and safety).

These briefings are held at the Test control point, CP-1, Area 6, NTS. Following these briefings, the $T C^{\prime}$ 's Advisory Panel, through the Scientific Advisor, makes a "go/no-go" recommendation to the " $T C$. If the recommendation is to proceed and the TC approves, a detonation time is established and the Test Execution Period begins (Figure 4). If not, the test is rescheduled.

On D-Day, a Readiness Briefing is held to update the panel, following which the Scientific Advisor recommends to the TC to proceed or to delay. If the decision is to proceed, the TC gives the TGD permission to arm. The TC, the TC's Advisory Panel, and supporting personnel continue to receive and evaluate real-time updates to the readiness status information. If the status remains favorable, the TC gives permission to start the countdown and permission to fire. If nothing abnormal occurs to suggest a halt to the countdown, the test proceeds to detonation.

MIGHTY OAK was scheduled for execution on April 8, 1986. Poor weather conditions caused two successive postponements. Finally, permission to fire MIGHTY OAK was granted on the morning of April 10. 


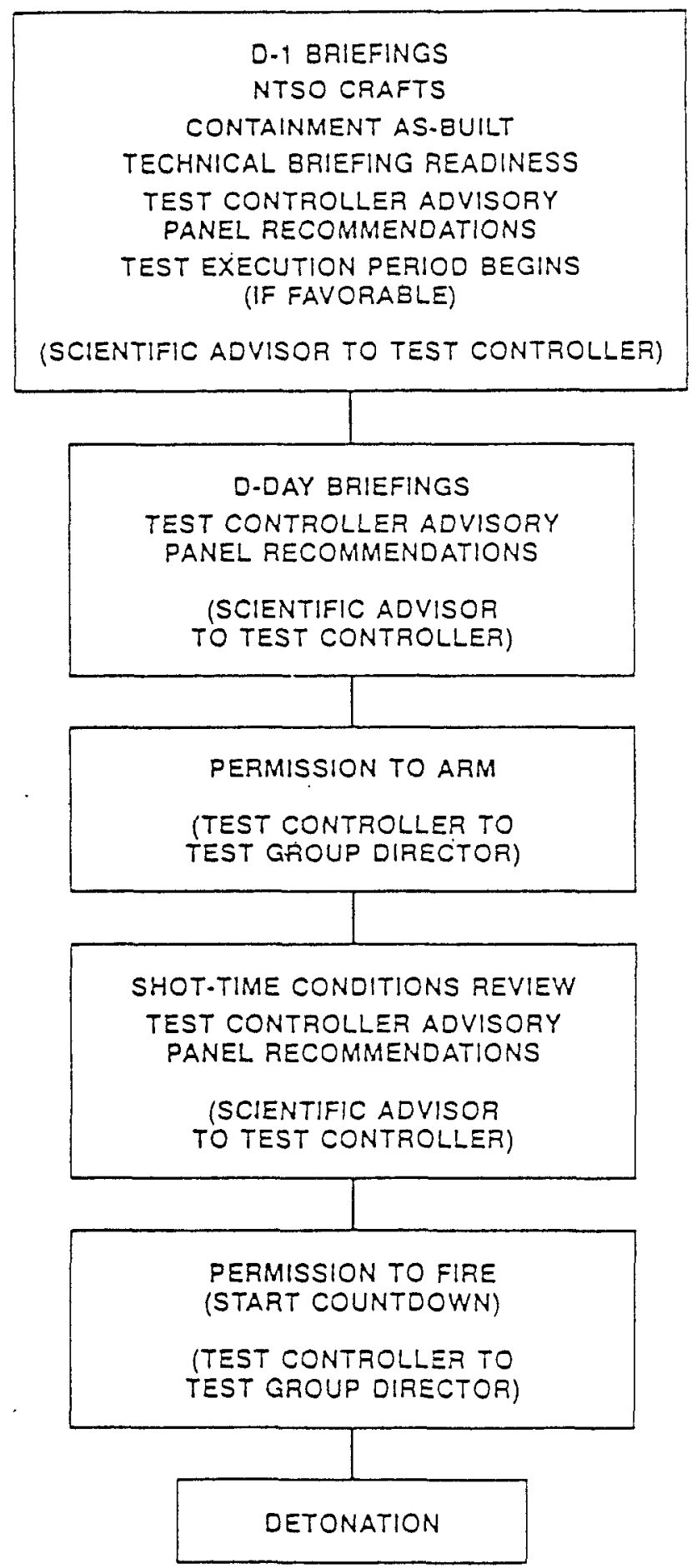

Figure 4. Test Execution Period Flow Chart $13 / 14$ 
SECTION $V$

TEST BED DESIGN

MIGHTY OAK was the fifth underground nuclear test to be conducted in the $T$ tunnel complex (see figures 1 and 2). The test bed consisted of a 911 foot-long tapered steel horizontal line-of-sight (HLOS) pipe with a nuclear device at one end and experiments at the other. Air was evacuated from the pipe to simulate exoatmospheric conditions. Besides the device and experiments, the pipe also contained several closure mechanisms. These mechanisms were designed to close very rapidly after passage of the radiation pulse. This design allowed experiments to be irradiated and still be protected from damage by debris generated by device detonation.

The MIGHTY OAK (U12t.08) drift complex is shown in more detail in Figure 5. Except for the open HLOS pipe itself, the regions from the working point (WP) out to 764 feet in the main drift and to 545 feet in the bypass drift were filled with stemming (backfill) materials prior to the test. The principal components of an HLOS pipe system included a device room, a muffler, a modified auxiliary closure (MAC), a gas seal auxiliary closure (GSAC), a tunnel and pipe seal (TAPS), and a test chamber for experiments. These components starting at the WP end and moving toward the portal may be described as follows:

- The device room is a rectangular steel box designed to house the device.

- The muffier is an expanded region of the HLOS pipe and is a feature designed to reduce the flow of energy down the pipe by allowing expansion and creating turbulence and stagnation.

- The MAC consists of a heavy steel housing containing two 12-inch-thick forged-aluminum doors. It is installed perpendicular to the HLOS pipe. The two doors are driven across the pipe from opposite sides so that each one completely blocks the HLOS pipe.

- The GSAC is similar to the MAC except that it is designed to provide a gas-tight closure.

- The TAPS consists of a steel housing containing a round steel door, hinged on the top edge. The door is held in the horizontal (open) position until detonation of the device at which time it is released to fall into the closed position. The TAPS can withstand 1,000-psi pressure and tolerate temperatures as high as $1,000^{\circ} \mathrm{F}$.

- The test chamber for MIGHTY OAK was about 14 feet in diameter and 51 feet long. The steel shell of the chamber was supported internally by stiffener rings on which experiments were mounted. MIGHTY OAK 


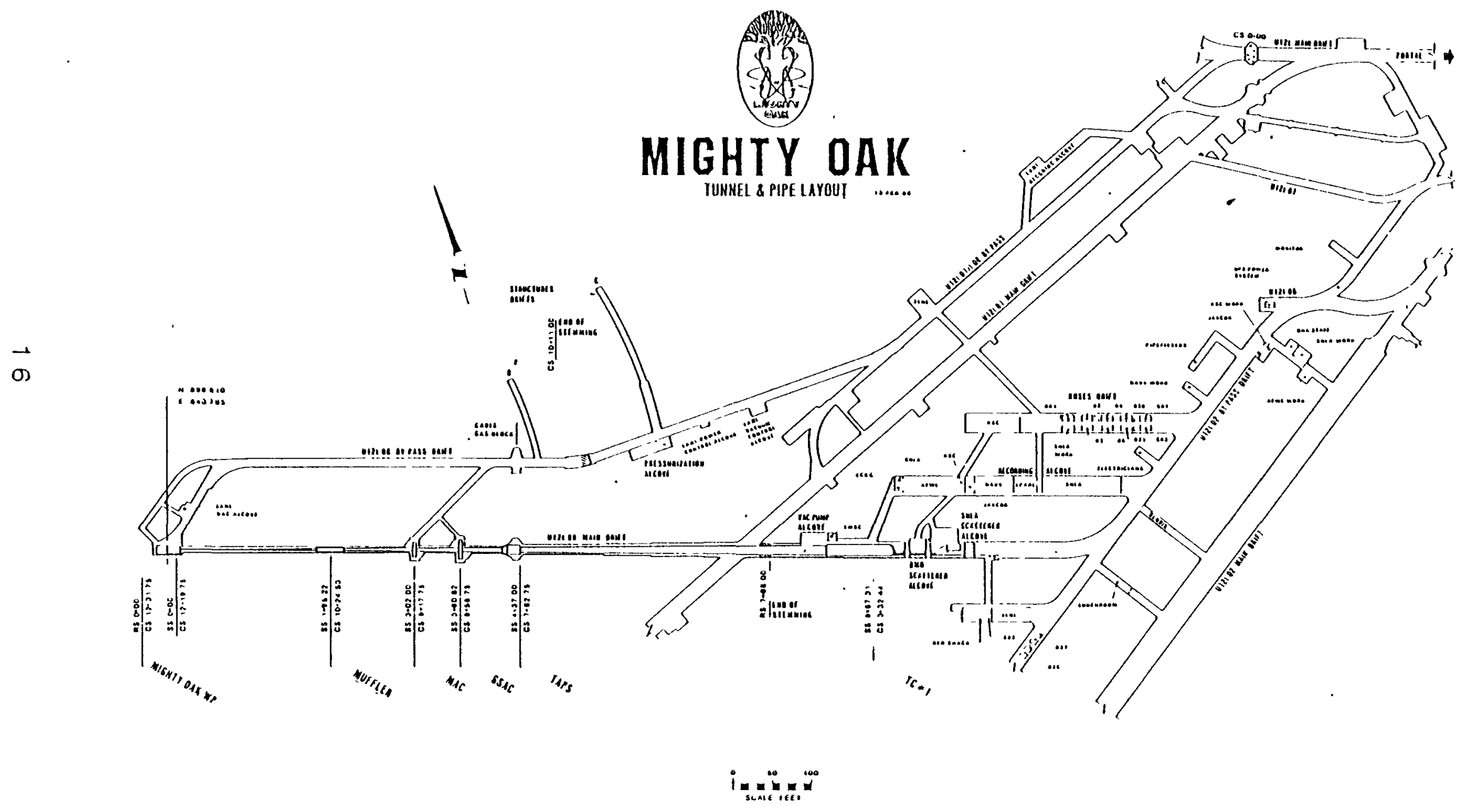

Figure 5. U121.08 Drift Tunnel and Pipe Layout 
experiments were either active or passive. Passive experiments were not instrumented and were designed to be recovered posttest for examination and analysis to establish test results. Active experiments were instrumented with various detectors and sensors to provide data prior to, during, and after the radiation arrival. Most of the MIGHTY OAK experiments (more than $85 \%$ ) were active.

The MAC and GSAC were designed to close in approximately 0.03 seconds to stop debris generated by the detonation. The TAPS was designed to close in about 0.75 seconds. 
SECTION VI

CONTAINMENT DESIGN

Containment is the prevention of the inadvertent release of radioactive material to the atmosphere. A CEP consisting of a group of experts in fields related to containment (geology, geophysics, hydrology, physics, explosion phenomenology, mathematics, engineering, etc.) has been established to review the containment design for every test scheduled at the NTS.

Responsibilities of the CEP include

- evaluating, as an independent organization, the containment design of each proposed nuclear test;

- ensuring that all relevant data available have been considered;

- advising the Manager, NV, on the technical adequacy of the emplacement design from the viewpoint of containment; and

- maintaining historical records of each evaluation.

While not a containment consideration, the prevention of excessive damage to, or contamination of, experiments and measuring equipment located underground is also an important goal.

To describe the containment design, the DNA uses the concept of a series of nested containment vessels. There were three such vessels on tne MIGHTY OAK test. Before radioactive material could reach the atmosphere, all three vessels would have had to be breached. Figure 2 shows the tunnel complex and outlines of the three containment vessels. They are described as follows:

Vessel I

Vessel I is the horizontal and vertical region surrounding the device, the expected blast cavity, and the stemmed tunnels. Design criteria required vessel I to withstand the effects of ground shock and contain the cavity temperature, pressure, and radiation.

1. Stemming Description

The stemmed region is that part of the tunnel that seals the blast cavity. Generally, stemming materials are sands, grouts, and concretes of varying strengths and properties. Stemming is placed around the HLOS pipe so that ground shock and the resultant ground motion close off the pipe and block the experiment tunnel to prevent 
the escape of radioactive material from vessel I. A stemming "plug" is formed when a sufficient amount of material is driven, under pressure, into the tunnel to block the HLOS pipe and to form an impermeable mass capable of withstanding the pressures and temperatures present in the cavity.

The ability to form a stemming plug is dependent upon the properties of the surrounding medium (the tunnel walls) and the properties of the stemining materials placed in the open tunnel spaces. Under the intense temperatures and pressures resulting from a nuclear explosion, some of the steming materials can flow like fluids and fill cracks and voids in the tunnel walls and in stronger concrete sections.

2. Mechanical Closures

When the HLOS pipe is closed by ground shock, there is a possibility that high-velocity gas and debris from the rapidly-closing pipe will? be jetted down the still-open HLOS pipe toward the experimental test chamber. To prevent or reduce this jetted flow, a series of fastacting closures are installed in the HLOS pipe. These are followed by a slower-acting closure to prevent late-time explosive and radioactive gases from entering the experimental chambers.

3. Penetrations

Penetrations of the stemming by pressurization lines, cables, chilledwater lines, water drain lines, etc., are all potential paths for radiation leakage to Vessel II, even if ground-shock stemming is successful. All of these penetrations are protected by a variety of sealing techniques, including check valves with high-burst-pressure ratings (10,000 psi) and gas blocks in cables and cable connectors. Mechanical closures are designed to meet criteria at 1,000 psi and $1,000^{\circ} \mathrm{F}$. Penetrations of the keyways into which the mechanical closures are set with concrete are required to meet the same criteria.

Drill holes in vessel I were used to insert or contain experiments, route cables, or take core samples of the rock surrounding the test complex. All of these drill holes were stemmed with grout or concrete having material properties that matched or surpassed those of the surrounding media.

Vessel II

Vessel II is the horizontal and vertical region surrounding al t tunnel volumes inside the Drift Protection Plugs (DPPS). Figure 2 shows the outline of Vessel II and locations of these plugs. The same basic construction techniques were used on all six of the DPps installed for MIGHTY OAK. The plugs were constructed of high-strength grout or concrete. The sides of the plugs toward the WP were constructed of steel, and all joints and penetrations were continuously seal-welded. The design criteria for these plugs on MIGHTY OAK called for them to withstand a pressure of 1,000 psi and a temperature of $1,000^{\circ} \mathrm{F}$. The same containment criteria applied to any penetration through these plugs. 
Vessel III

Vessel III is the horizontal and vertical region surrounding all tunnel volumes inside the Gas Seal Plug (GSP). Figure 2 shows the outline of this third vessel. The MIGHTY OAX tunnel volume between the GSP and the DPPS region was nearly one million cubic feet. This volume was considered great enough to reduce any temperature and pressure that the GSP could experience to less than the design criteria.

The GSP is a massive concrete plug, approximately 15 feet thick, keyed into the tunnel walls and anchored with concrete. It is designed to withstand pressures to 500 psi and temperatures to $500^{\circ} \mathrm{F}$. All penetrations of the GSP and its concrete anchor are also designed to withstand these conditions. Figure 2 shows the location of the GSP.

Beyond the GSP is the gas seal door (GSD). This door is outside vessel II and is not considered a part of the containment design. As an additional safety measure, prior to device detonation, the GSO is closed and the tunnel between it and the GSP is pressurized to approximately 10 psi. This pressure can be controlled and increased if necessary.

The MIGHTY OAK containment plan was considered to be an improvement over recent HLOS containment designs. The improvements were not major changes and the basic design was similar to most successfully contained events. 


\section{SECTION VII \\ GEOLOGY}

The MIGHTY OAK WP was about 1,300 feet beneath the surface of the eastern end of Rainier Mesa, known as Aqueduct Mesa. The geologic characteristics of this area are well known because of current and previous geological investigations of nearby WPS. MIGHTY OAX was located in the same geologic formation in which previous events were successfully contained, and there was no known geological reason to suggest that MIGHTY OAK would behave any differently. Other adjacent rock formations were not expected to have any impact on containment, nor was the water table, which was located below the region of interest. Furthermore, there were no major structural faults in the vicinity of the MIGHTY OAK WP. 


\section{SECTION VIII}

RADIOLOGICAL SAFETY OPERATIONS AND AREA CONTROLS

On-Site Radiological Safety Arrays

On every nuclear test, Remote Area Monitoring System (RAMS) units (devices used in the detection and measurement of gamma radiation) are positioned in the immediate vicinity of surface ground zero (SGZ). For the MIGHTY OAK- tunnel test, RAMS units were placed throughout the test tunnel complex, the main arift, the portal area, and on top of Rainier Mesa (Figures 6 and 7 ). In addition, an extensive network of radiation detectors, air samplers, thermoluminescent dosimeters, and noble gas samplers are permanently positioned throughout the NTS. Data readouts of the surface and underground RAMS were displayed in the Test Control Center to provide early indications of any potential problems to the TC and his Advisory Panel.

\section{Off-Site EPA Monitoring}

As with all nuclear tests, the EPA deployed. personnel and equipment in the off-site area downwind from the test location to measure any airborne radioactivity-that might be released as a result of the test. The operating procedures of these personnel, and the fixed monitoring network around the NTS are described in annual reports.* off-site monitoring program status, locations and plans of off-site monitoring personnel were presented to the TC's Advisory Panel at the D-1 and D-day briefings.

\section{Pretest Safety and Planning Meeting}

Pretest safety and planning is a continuing process throughout all stages of fielding a nuclear explosive test at the NTS. Containment designs and engineering plans are thoroughly reviewed with a paramount concern for safety of Test site workers and the general public. On or about $0-7$, a further step in this sequence occurs when the the TC convenes a planning and safety review meeting at which he, his Scientific Advisory Panel and other support personnel are briefed by the sponsoring agency TGO, WSNSO, EPA, and DOE operations personnel on various test-related technical, operational, and safety interests. The MIGHTY OAK Safety and Planning meeting was held on March 28, 1986, at noon.

On D-1, the above personnel were again briefed by the TGD on all test updates. No unresolved issues were identified at this meeting.

\footnotetext{
"Off-Site Environmental Monitoring Report," the latest issue of which has the report number EPA-600/4-86-022.
} 


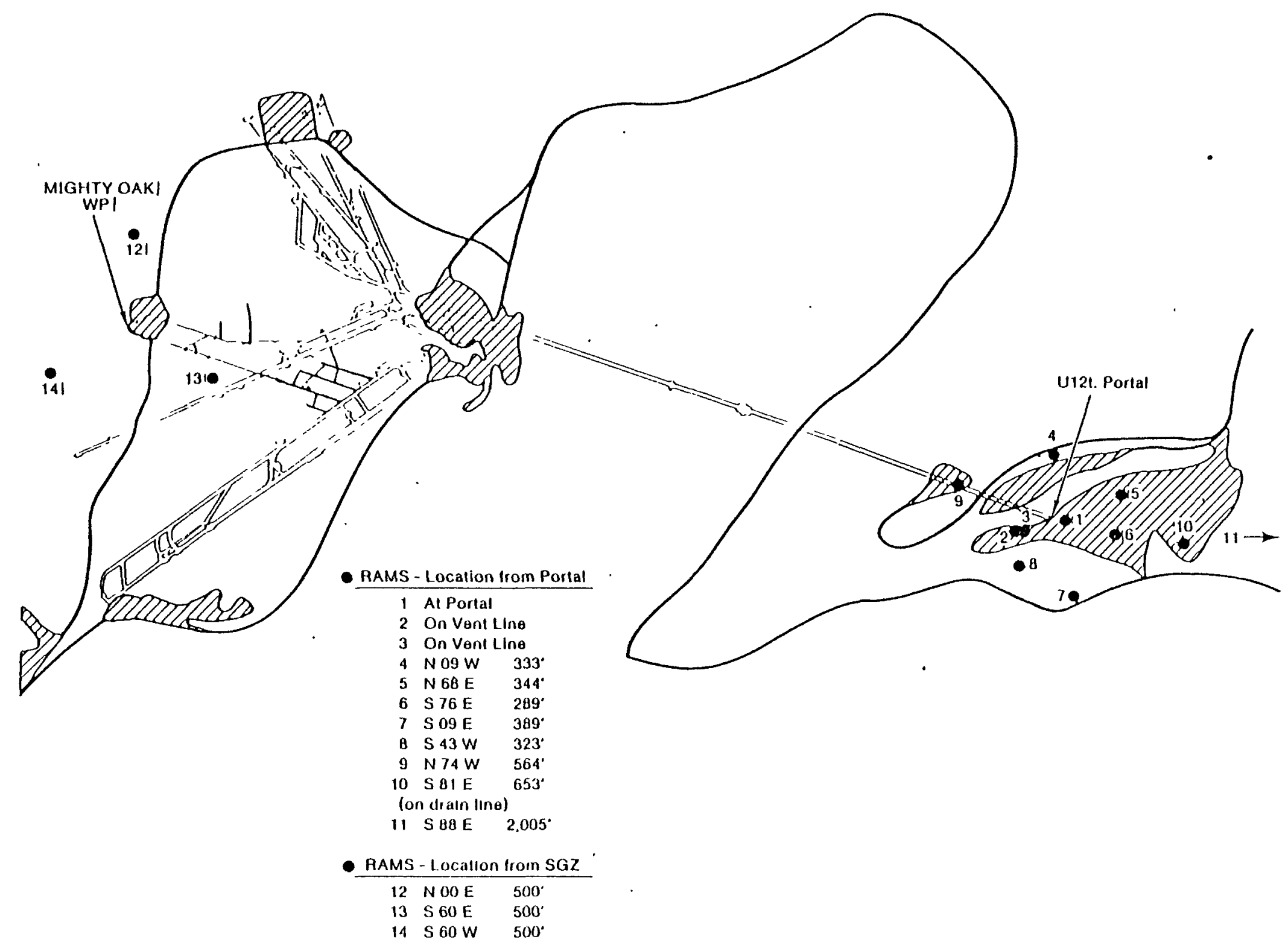

Figure 6. Surface RAMS Unit Locations 


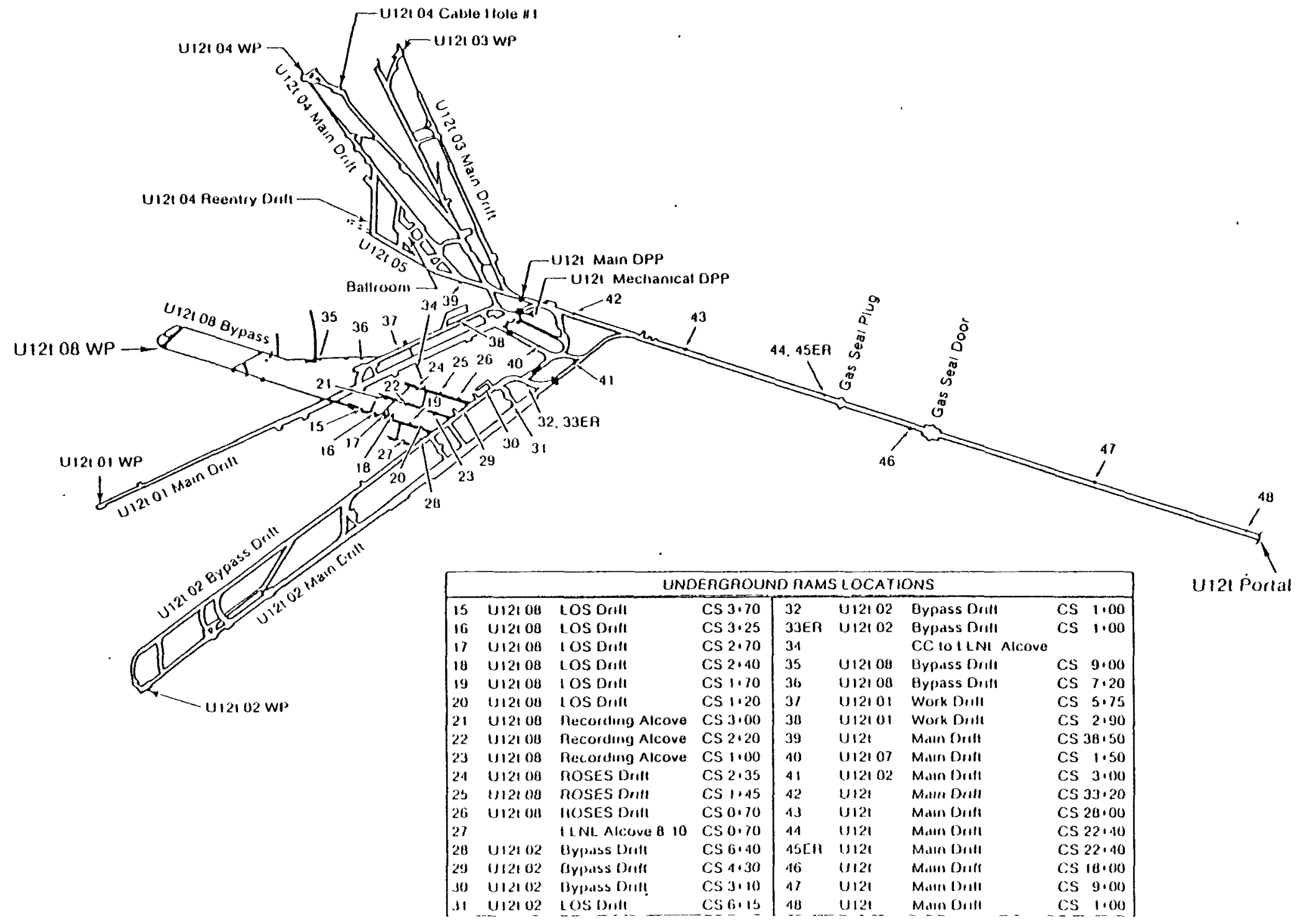

Figure 7. Underground RAMS Unil Localions 
SECTION IX

TEST EXECUTION

The MIGHTY OAK test originally was scheduled for April 8, 1986. On 0-1, April 7 , standard readiness briefings were conducted to confirm MIGHTY OAK readiness to proceed (Figure 4 ). These briefings included:

1. Updates by the TGD.

2. A detailed review of the containment features. Several minor "asbuilt" changes from the original construction plan presented to the CEP on October 3, 1985, were discussed. Responsible containment scientists present concurred that the changes were minor and that they did not require being referred back to the CEP. Representatives from Waterways Experiment Station, Fenix \& Scisson, Inc., Holmes \& Narver, Inc., LANL, LLNL, and Reynolds Electrical and Engineering Company, Inc. (REECO), concurred with the data presented.

3. Review by the TC, the Scientific Advisory Panel, the TGD and supporting elements of the test readiness posture. Among the topics reviewed were:

a. Technical Program Readiness.

b. Current weather conditions and predicted weather for the scheduled detonation time.

c. Debris cloud trajectories, radiological deposition patterns, and calculated exposures based on an appropriate accident release model and on the predicted weather conditions for detonation time.

d. Calculated whole-body and thyroid radiation doses to people within the postulated off-site exposure pattern in the unlikely event an accidental release of radioactive material should occur; locations of people and milk cows in vulnerable positions within tne pattern; and off-site monitoring program status and response plans.

e. On-site radiation monitoring program status and plans.

f. Plans for NTS craft activities and emergency support should an accidental release occur.

g. On-site control and area clearance plans, manned/stay-in stations, air support missions, geophones, closed-circuit television coverage, and any other special arrangements. 
From information presented at the briefings, it was apparent that winds compatible with DOE safety criteria were unlikely for April 8 . The test was delayed for 24 hours. Weather and fallout predictions for April 9 were reviewed on the afternoon of April 8. They were deemed promising enough to warrant establishing a tentative detonation time for 9:00 a.m., April 9. During the early morning D-Day briefings on April 9 , it was determined that weather conditions were only marginally acceptable. The panel recommended monitoring of weather throughout the day until a completely favorable wind regime developed. This regime did not develop and the test was rescheduled for the morning of April 10.

At the early morning D-Day weather briefing on April 10, weather predictions, potential fallout patterns, technical readiness, and on- and off-site controls were all reviewed again and determined to meet operational readiness and safety criteria. The $T C^{\prime} s$ Panel recommended that the test proceed and MIGHTY OAK was detonated at 6:08 a.m. As expected, the device had a yield of less than 20 kilotons of equivalent high explosive (TNT).

No radiation associated with the dynamic effects of the detonation was released to the atmosphere. 


\section{SECTION $X$ \\ POSTTEST ACTIVITIES}

\section{Early-Time Observations}

At zero time, all RAMS units and air samplers had been calibrated and were fully operational. Shortly after detonation, RAMS units located in Vessel II indicated radiation at levels greater than $1,000 \mathrm{R} / \mathrm{h}$. Within a few minutes, all RAMS units inside containment vessel II ceased functioning. At this time, it became obvious that radioactive material had leaked from Vessel I, into vessel II, and into vessel III, where it was successfully contained. Radiation levels peaked within a few hours and then began to decay. No RAMS units beyond containment vessel III detected radiation readings associated with the dynamic phase of the test (see Figure 2 ).

At $6: 53 \mathrm{a} . \mathrm{m}$. , the Blue Bird team (REECo Mobile Radiation Monitoring team) was directed to move from Security Station 700 (see Figure 8) to the junction of the 12-01 Road and Rainier Mesa Road (R-64). This move was made to provide additional monitoring support in case containment vessel III was breached and radiation leaked past the GSD. No breach took place and no radiation readings above background levels were detected. The team was released at 10:38 a.m. At this same time, a Wackenhut Services, Inc. (WSI) guard station with a radiological safety monitor was established on the 12-01 Road to control access to the portal area.

At 9:15 a.m., a portal survey and damage assessment team, along with a limited number of experimenters, departed Security Gate 300 for the $T$ tunnel portal to conduct the initial portal survey. A data recovery team started recovery from the portal recording station and SNL trailers at 10:25 a.m. Data recovery and damage assessment were completed by noon, and all personnel moved back to the 12-01 access road security station.

A "stand down" order was issued at that time; however, on- and off-site radiation monitoring continued throughout the day and night. Precautions were taken during the night to ensure that all personnel in the potential downwind area were identified and could be evacuated if necessary.

On-site monitoring and area controls were relaxed during the next few days because no radiation was detected outside of Vessel III and the RAMS display in the Test Control Center showed radiation levels inside the tunnel falling at the expected decay rates.

On April 14, 1986, two days prior to tunnel purging, a crew went to the portal and obtained gas samples using the portal remote gas sampling system. A second crew began installing a system to purge that portion of the tunnel between the GSD and the portal face of the GSP (see Figure 7) in preparation for a manned reentry into the tunnel. 


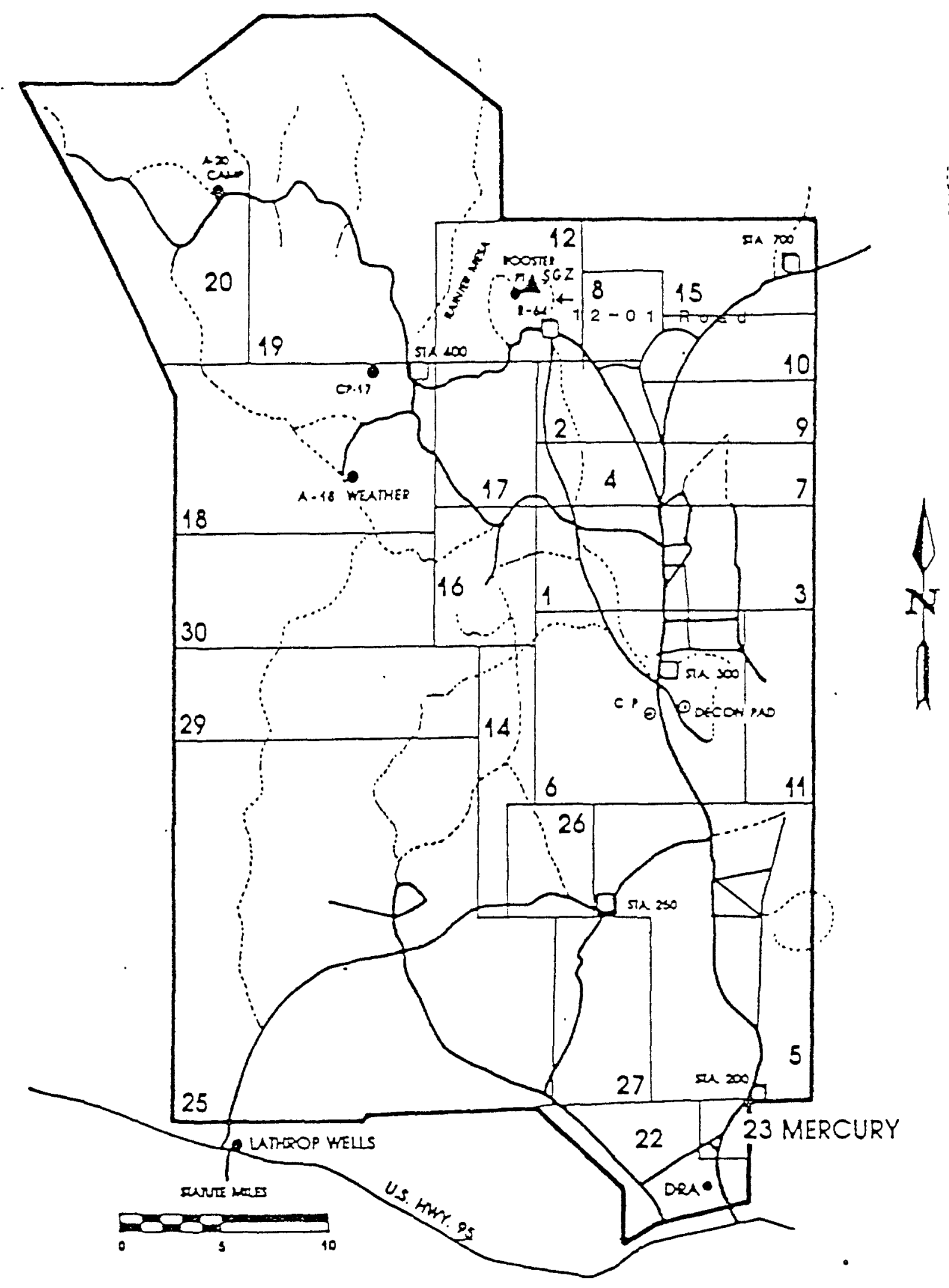

Figure 8. Map of the Nevada. Test Site 
On April 15, a reentry team prepared to obtain gas samples from the wp side of the GSP when it was discovered that gas samples taken the day before between the GSP and OPP showed detectable iodine. The team postponed reentry until conditions could be assessed.

On April 16, at 8:15 a.m., the reentry team again received permission to enter the portal and proceed to the GSD to prepare the tunnel for purging. After completing this task, the system was configured to purge up to the portal side of the DPDs. The reentry team exited the portal.

Tunnel Purging

Following every test conducted in an NTS tunnel, the air contained within the tunnel complex is mechanically ventilated to the outside and replaced with clean air. Absence of radionuclides in the tunnel air would simplify the process in terms of controlling release of radioactivity to the outside environment, but would not eliminate the need for air replacement to remove noxious gases and/or possible explosive gases from the tunnel.

RAMS readings within the MIGHTY OAK tunnel indicated the presence of radioactive materials. Confirmation was obtained through analysis of gas samples taken with a gas sampling system installed in the tunnel complex prior to detonation. The DOE TC notified the EPA that procedures would be instituted within the next few days to purge the tunnel so that personnel could safely reenter the tunnel to recover equipment and records. EPA notified off-site residents and established special sampling stations to monitor off-site conditions: The TC also requested the WSNSO to monitor meteorological conditions. On April 15, 1986, state of Nevada health officials were notified of DOE plans to begin purging.

\section{Purging Procedures}

During purging activities, small quantities of radioactive gases may be intentionally released to the atmosphere under carefully-controlled, filtered conditions to limit potential exposures. Purging is normally delayed for some time after detonation to allow the decay of many short-lived fission products. Purging rate is controlled to avoid overloading filters and to permit adequate monitoring. In addition, purging takes place only under optimum meteorological conditions to ensure that any off-site radiation doses will be within International Commission on Radiological Protection guides and EPA airborne radionuclide emission guidelines.

\section{Purging Schedule}

The first scheduled purging of tunnel gases from the MIGHTY OAK test occurred on April 16, 1986, six days after the test. At that time, a small amount of contaminated air was released through a filtration system to relieve excess pressure from within the tunnel. This purging lasted for about 15 minutes. No radiation from this release was detected off-site. The next purging was conducted on April 22. Subsequent purgings were conducted during the times of favorable meteorological conditions until May 5. At that time, continuous ventilation was approved since radioactivity remaining in the tunnel was very low and steadily decreasing. 
Virtually all of the particulate radioactivity and a significant portion of the radioiodines were removed by filtration prior to discharge. Because radioactive noble gases are not removed by the filter system, it was expected that radioxenon would be found in measurable concentrations outside the tunnel.

During and following the purge period, special samplers were operated by the EPA at near off-site locations for sampling of radionuclides in the ambient air.

Throughout the purging period, bulletins were provided to Community Monitoring station managers and residents in nearby, off-site communities.

3. Off-Site Sampling and Controls

The planned purging schedules were provided to EPA so that special noble gas samplers and air samplers equipped with particulate and charcoal filters could be deployed to supplement the routine (permanent station) monitoring networks. Figure 9 shows the downwind sector for acceptable surface winds prerequisite to, and during, purging.

\section{Monitoring Results}

Analyses of the off-site samples for radioactive noble gases and other gamma-emitting radionuclides indicated that only low levels of xenon133 were detectable in populated areas near. the NTS. The estimated maximum dose an individual could have received was calculated to be 0.27 microrem. This assumes that the recipient remained in the open at the measurement site during the entire period of the purging. This dose is equivalent to less than 1-1/2 minutes extra exposure to natural background radiation at that location. Only xenon-133 was detectable off-site, and no radioactivity attributable to MIGHTY OAK was detectable after May 5, 1986. Tables 1 and 2 include the results for noble gas and air filter samples, respectively.

The Chernobyl nuclear reactor disaster began in the Soviet Union on April 26, resulting in subsequent world-wide transport of airborne radioactivity. Chernobyl-related airborne radioactivity was subsequently detected in the NTS off-site area* during the period of postMIGHTY OAK purging. Air samples collected May 6 from Colorado and Utah contained the first indications of Chernobyl fallout (see footnote to Table 2). The highest concentrations of iodine-131 in Nevada during post-MIGHTY OAK monitoring occurred at Reno, Nevada, rather than downwind from the NTS, again, implicating Chernobyl debris as the source. Additionaliy, cesium-134, an activation product which accumulates in nuclear power reactors, but is produced in negligible amounts in nuclear explosions, was detected by the EPA off-site air sampling network, confirming Chernobyl as the source of that radioactivity.

*"Off-Site Monitoring of the MIGHTY OAK Nuclear Test," EPA 600/4-86-030, dated July 1986. 


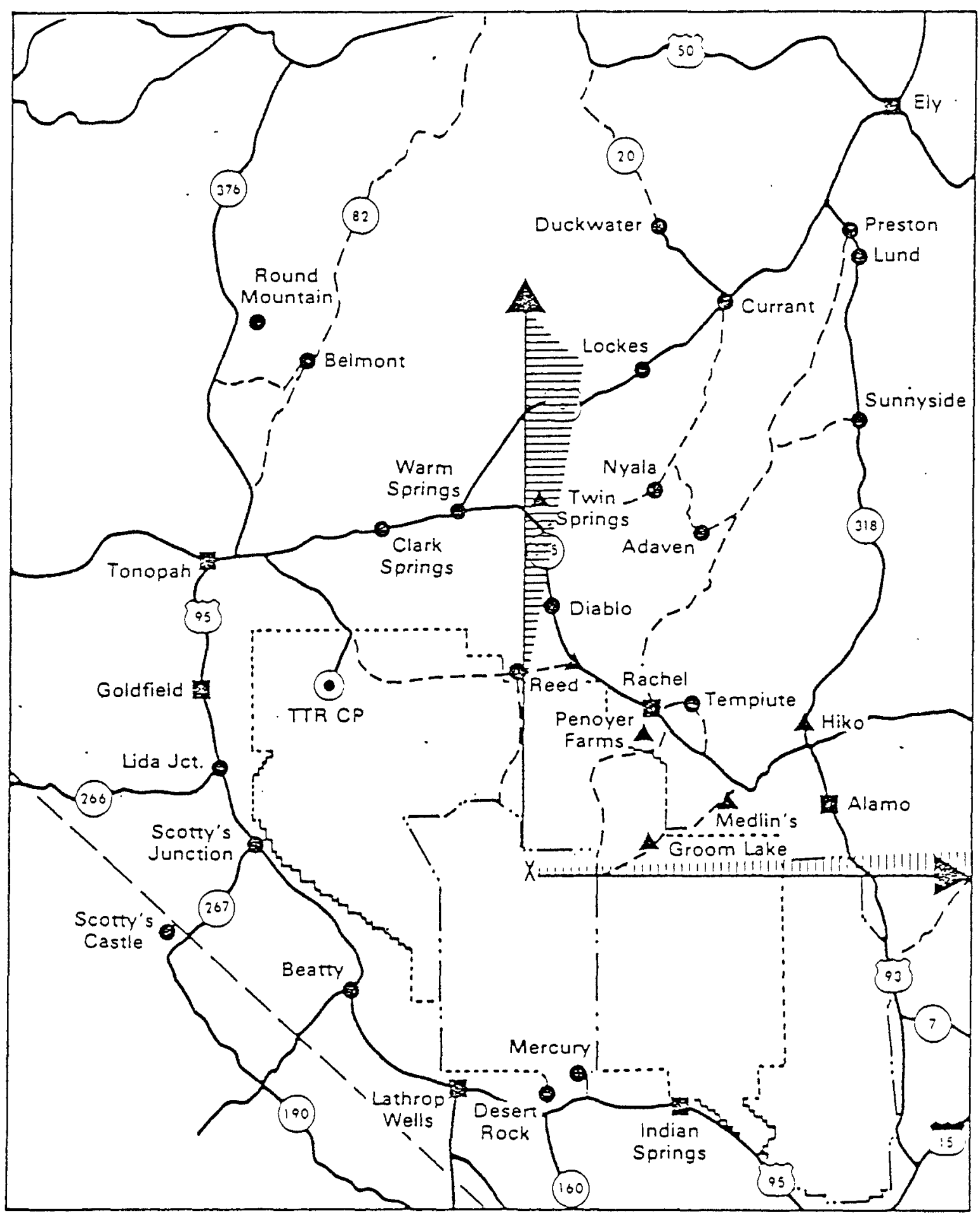

Routine Sampling Locations

A Special Sampling Locations

Figure 9 . Special Sampler Locations and Acceptable Wind Sector 
TABLE 1

XENON-133 SPECIAL STUDY-MIGHTY OAK

\begin{tabular}{|c|c|c|c|c|}
\hline Location & $\begin{array}{l}\text { Start } \\
\text { (day) }\end{array}$ & $\begin{array}{l}\text { Start Time } \\
\text { (hour) }\end{array}$ & $\begin{array}{l}\text { Run Time } \\
\text { (hours**) }\end{array}$ & $\begin{array}{l}\text { Result } \\
\mathrm{pCi} / \mathrm{m}^{3}\end{array}$ \\
\hline Al amo, NV & $\begin{array}{l}04 / 09^{*} \\
04 / 16 \\
04 / 16^{\star} \\
04 / 23^{\star} \\
04 / 30^{\star}\end{array}$ & $\begin{array}{l}1030 \\
1140 \\
1150 \\
1230 \\
1145\end{array}$ & $\begin{array}{r}169 \\
23 \\
167 \\
168 \\
169\end{array}$ & $\begin{array}{c}\text { NDt } \\
\text { ND } \\
\text { ND } \\
30+5 \\
N \bar{D}\end{array}$ \\
\hline Reed $R n$. Turnoff & $04 / 22$ & 1030 & 23 & $64 \pm 10$ \\
\hline Glendale, NV & $04 / 25$ & 1200 & 25 & ND \\
\hline Groom Lake & $\begin{array}{l}04 / 16 \\
04 / 22 \\
04 / 25 \\
04 / 28 \\
04 / 29 \\
04 / 30 \\
05 / 05 \\
05 / 09\end{array}$ & $\begin{array}{l}1105 \\
1130 \\
1130 \\
1010 \\
1100 \\
1130 \\
1445 \\
1015\end{array}$ & $\begin{array}{r}20 \\
24 \\
23 \\
25 \\
24 \\
120 \\
9 ? \\
165\end{array}$ & $\begin{array}{c}N D \\
N D \\
330 \pm 10 \\
N 30 \pm 15 \\
N \overline{N D} \\
N D \\
52 \pm 9\end{array}$ \\
\hline Hiko, NV & $\begin{array}{l}04 / 16 \\
04 / 21 \\
04 / 25 \\
04 / 28 \\
04 / 30 \\
05 / 05\end{array}$ & $\begin{array}{l}1100 \\
1300 \\
1100 \\
1030 \\
1100 \\
1130\end{array}$ & $\begin{array}{r}23 \\
48 \\
23 \\
48 \\
120 \\
95\end{array}$ & $\begin{array}{c}\text { ND } \\
\text { ND } \\
220 \pm 7 \\
92 \pm 20 \\
\text { ND } \\
\text { ND }\end{array}$ \\
\hline Pioche, NV & $04 / 22$ & 1100 & 96 & ND \\
\hline
\end{tabular}

NOTE: Data shown represent corrections to data listed in "Off-site Monitoring for the MIGHTY OAK Nuclear Test," EPA 600/4-86-030, dated July 1986.

*Noble Gas and Tritium Surveillance Network (see Table 3).

$\star \star$ Run time following start day and hour.

$T N D=$ not detected. 
TABLE 1 (CONCLUDED)

\begin{tabular}{|c|c|c|c|c|}
\hline Location & $\begin{array}{l}\text { Start } \\
\text { (day) }\end{array}$ & $\begin{array}{l}\text { Start Time } \\
\text { (hour) }\end{array}$ & $\begin{array}{l}\text { Run Time } \\
\text { (hours**) }\end{array}$ & $\begin{array}{l}\text { Result } \\
\mathrm{pCi} / \mathrm{m}^{3}\end{array}$ \\
\hline Rachel, NV & $\begin{array}{l}04 / 19^{\star} \\
04 / 16 \\
04 / 16^{\star} \\
04 / 23^{\star} \\
04 / 30^{\star}\end{array}$ & $\begin{array}{l}0930 \\
1040 \\
1015 \\
1200 \\
1000\end{array}$ & $\begin{array}{r}168 \\
22 \\
168 \\
166 \\
169\end{array}$ & $\begin{array}{c}\text { ND } \\
\text { ND } \\
\text { ND } \\
29 \pm 5 \\
20 \pm 6\end{array}$ \\
\hline Penoyer Farm & $\begin{array}{l}04 / 22 \\
04 / 25 \\
04 / 28 \\
04 / 30 \\
05 / 05\end{array}$ & $\begin{array}{l}1200 \\
1000 \\
1115 \\
1245 \\
1400\end{array}$ & $\begin{array}{r}22 \\
17 \\
49 \\
121 \\
92\end{array}$ & $\begin{array}{c}18+5 \\
N \bar{D} \\
160 \pm 7 \\
29 \pm 7 \\
N \bar{D}\end{array}$ \\
\hline $\begin{array}{l}\text { Medlin Rn. } \\
\text { (Tikaboo VAlley) }\end{array}$ & $\begin{array}{l}04 / 16 \\
04 / 22 \\
04 / 25 \\
04 / 28 \\
04 / 30\end{array}$ & $\begin{array}{l}1130 \\
0800 \\
1300 \\
1235 \\
1130\end{array}$ & $\begin{array}{r}22 \\
28 \\
11 \\
47 \\
120\end{array}$ & $\begin{array}{c}\text { ND } \\
\text { ND } \\
430 \pm 15 \\
94 \div 6 \\
\text { ND }\end{array}$ \\
\hline Twin Springs $R n$. & $\begin{array}{l}04 / 21 \\
04 / 25 \\
04 / 30 \\
05 / 05\end{array}$ & $\begin{array}{l}1020 \\
1000 \\
1430 \\
1500\end{array}$ & $\begin{array}{r}48 \\
26 \\
120 \\
92\end{array}$ & $\begin{array}{c}\text { ND } \\
\text { INSUFF. } \\
92+9 \\
\text { ND }\end{array}$ \\
\hline
\end{tabular}

NOTE: Data shown represent corrections to data listed in "Off-site Monitoring for the MIGHTY OAK Nuclear Test," EPA 600/4-86-030, dated July 1986.

*Noble Gas and Tritium Surveillance Network (see Table 3 ).

**Run time following start day and hour.

$+N D=$ not detected. 
TABLE 2

SPECIAL AIR FILTER SAMPLES - pCi/m

\begin{tabular}{|c|c|c|c|c|c|c|c|c|c|}
\hline LOCATION & $4 / 17$ & $4 / 23$ & $4 / 26$ & $4 / 30$ & $5 / 5$ & $5 / 7$ & $5 / 8$ & $5 / 5-5 / 9$ & $5 / 10$ \\
\hline ALAMO & GSN* & GSN & GSN & GSN & & & & $\begin{array}{c}I-13 I- \\
0.5\end{array}$ & $\begin{array}{c}1-131- \\
1.2\end{array}$ \\
\hline Glendale & & & GSN & & & & & & \\
\hline Groom Lake & GSN & & GSN & GSN & $G S N * *$ & & & $\begin{array}{c}1-131- \\
0.2\end{array}$ & $\begin{array}{c}1-131- \\
1.9\end{array}$ \\
\hline Hiko & GSN & GSN** & GSN & GSN & GSN & & & $\begin{array}{c}1-131- \\
0.2\end{array}$ & $\begin{array}{c}1-131- \\
1.2\end{array}$ \\
\hline Lathrop Wells & GSN & GSN & GSN & GSN & GSN & GSN & $\begin{array}{c}I-131- \\
0.10\end{array}$ & $\begin{array}{c}I-131- \\
0.9\end{array}$ & $\begin{array}{c}1-131- \\
1.9\end{array}$ \\
\hline Medlin Rn. & GSN & GSN** & GSN & GSN & GSN & & & & \\
\hline Penoyer Farm & & GSN & GSN & GSN & GSN & & & $\begin{array}{r}I-131 \\
0.20\end{array}$ & \\
\hline Pioche & & & GSN & & & & & & \\
\hline Rachel & GSN & GSN & & GSN & GSN & GSN & GSN & & $\begin{array}{c}1-131- \\
1.5\end{array}$ \\
\hline $\begin{array}{l}\text { Reed Rn. } \\
\text { Turnoff }\end{array}$ & & $G S N * \star$ & & & & & & & \\
\hline Twin Springs & & $G S N * \star$ & GSN & & GSN & GSN & GSN & $\begin{array}{c}1-131- \\
0.1\end{array}$ & $\begin{array}{c}1-131- \\
4.6\end{array}$ \\
\hline
\end{tabular}

NOTE: First detectable Chernobyl fallout found $5 / 7$ in air samples from Denver, CO; Elko, NV; Delta, Milford, and Bryce Canyon, UT; and in snow from Mt. Charleston.

$\star G S N=$ gamma spectrum negligible

**beryllium-7 detected, a natural radionuclide 
The EPA monitoring network around the NTS is the only one in the U.S. routinely analyzing noble gas samples for xenon. These monitoring stations are deliberately clustered near the NTS to monitor for emissions from the NTS. Special samplers located at. Twin Springs Ranch, Penoyer Farm, Hiko, and Groom Lake were operated from May 5 to May 9 during continuous purging of the tunnel. No sample collected during this period had concentrations of radionuclides above detection limits. The positive results (for May 5-21) from the routine noble gas monitoring stations were coincident with arrival of particulate radioactivity from Chernobyl (see Table 3) and have been attributed to chernobyl. These stations collect air at a very low sampling rate so that one cubic meter of air is collected over a one-week interval. Thus, reported concentrations represent the average radionuclide concentrations for a one-week period. 


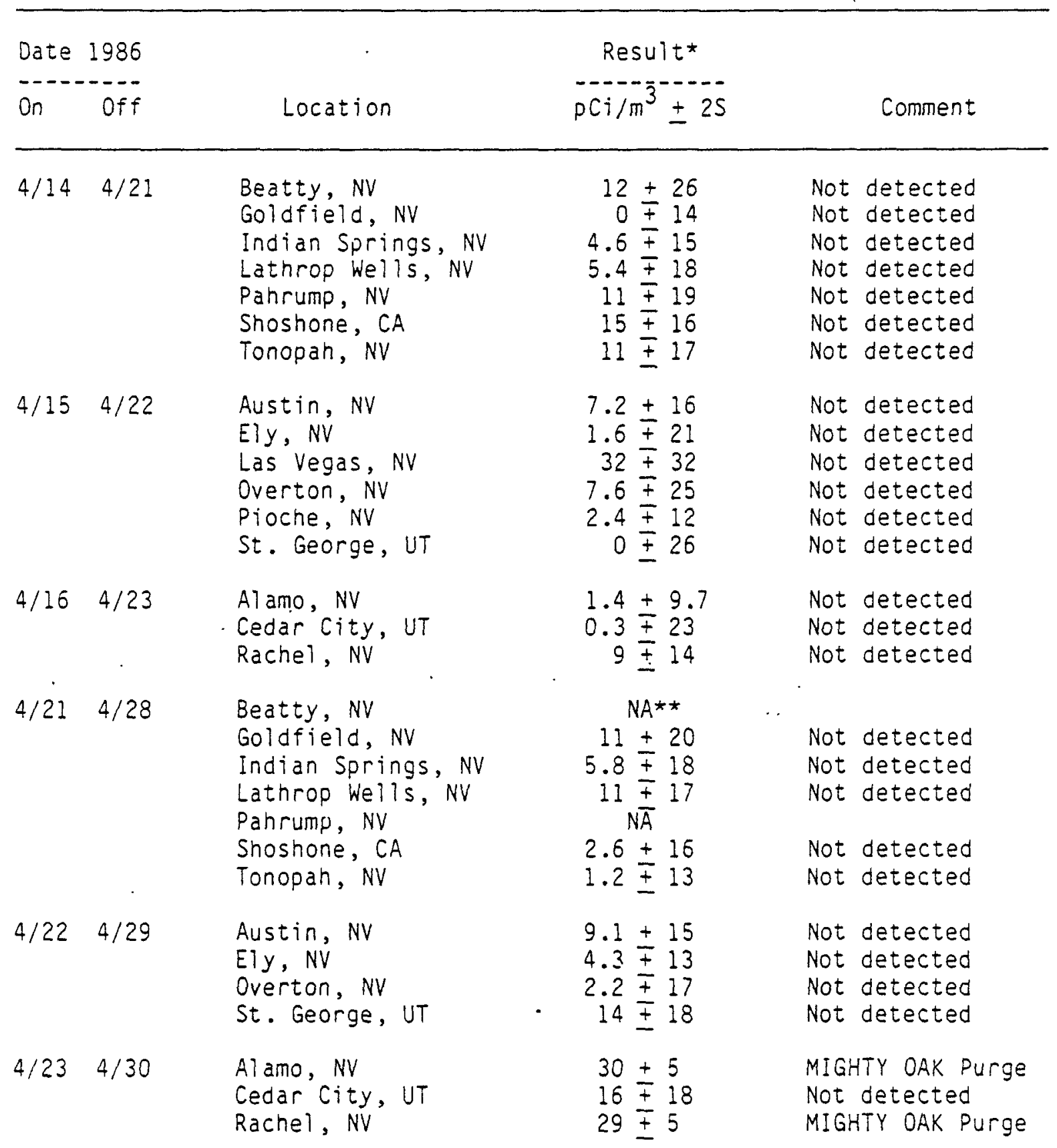

\footnotetext{
*Not detected when first value is less than the two-standard-deviation error of counting (second value).

*NA = Not analyzed, either lost sample or insufficient amount. All samples collected later than the above contained non-detectable amounts of Xenon-133.
} 
TABLE 3 (CONTINUED)

\begin{tabular}{|c|c|c|c|c|}
\hline \multicolumn{2}{|c|}{ Date 1986} & \multicolumn{3}{|c|}{ Result* } \\
\hline On & off & Location & $\mathrm{pCi} / \mathrm{m}^{3} \pm 2 \mathrm{~S}$ & Comment \\
\hline $4 / 28$ & $5 / 5$ & $\begin{array}{l}\text { Beatty, NV } \\
\text { Goldfield, NV } \\
\text { Indian Springs, NV } \\
\text { Lathrop Wells, NV } \\
\text { Pahrump, NV } \\
\text { Shoshone, CA } \\
\text { Tonopah, NV }\end{array}$ & $\begin{array}{l}9.6 \pm 21 \\
0 \pm 15 \\
N \bar{A} \\
0 \pm 22 \\
N \bar{A} \\
0.7 \pm 11 \\
1.2 \pm 12\end{array}$ & $\begin{array}{l}\text { Not detected } \\
\text { Not detected } \\
\text { Not detected } \\
\text { Not detected } \\
\text { Not detected }\end{array}$ \\
\hline $4 / 29$ & $5 / 6$ & $\begin{array}{l}\text { Austin, NV } \\
\text { Ely, NV } \\
\text { Las Vegas, NV } \\
\text { Overton, NV } \\
\text { St. George, UT }\end{array}$ & $\begin{array}{l}0.4 \pm 13 \\
8.1 \pm 14 \\
4.4 \pm 15 \\
N \overline{N A} \\
20 \pm 26\end{array}$ & $\begin{array}{l}\text { Not detected } \\
\text { Not detected } \\
\text { Not detected } \\
\text { Not detected }\end{array}$ \\
\hline $4 / 30$ & $5 / 7$ & $\begin{array}{l}\text { Alamo, NV } \\
\text { Cedar City, UT } \\
\text { Rachel, NV }\end{array}$ & $\begin{array}{c}2.1 \pm 10 \\
20 \pm 6\end{array}$ & $\begin{array}{l}\text { Not detected } \\
\text { MIGHTY OAK PURGE }\end{array}$ \\
\hline $5 / 5$ & $5 / 12$ & $\begin{array}{l}\text { Beatty, NV } \\
\text { Goldfield, NV } \\
\text { Indian Springs, NV } \\
\text { Lathrop Wells, NV } \\
\text { Pahrump, NV } \\
\text { Shoshone, CA } \\
\text { Tonopah, NV }\end{array}$ & $\begin{array}{l}39 \pm 10 \\
45 \pm 7 \\
43 \pm 6 \\
37 \pm 15 \\
N \bar{A} \\
24 \pm 6 \\
57 \pm 14\end{array}$ & $\begin{array}{l}\text { Chernobyl } \\
\text { Chernobyl } \\
\text { Chernobyl } \\
\text { Chernobyl } \\
\text { Chernobyl } \\
\text { Chernobyl }\end{array}$ \\
\hline $5 / 6$ & $5 / 13$ & $\begin{array}{l}\text { Austin, NV } \\
\text { Ely, NV } \\
\text { Las Vegas, NV } \\
\text { Overton, NV } \\
\text { St. George, UT }\end{array}$ & $\begin{array}{l}54 \pm 10 \\
36 \pm 7 \\
67 \pm 11 \\
30 \pm 9 \\
16 \pm 17\end{array}$ & $\begin{array}{l}\text { Chernobyl } \\
\text { Chernobyl } \\
\text { Chernobyl } \\
\text { Chernobyl } \\
\text { Not detected }\end{array}$ \\
\hline $5 / 7$ & $5 / 14$ & $\begin{array}{l}\text { Alamo, NV } \\
\text { Cedar City, UT } \\
\text { Rachel, NV }\end{array}$ & $\begin{array}{l}40 \pm 5 \\
N \bar{A} \\
45 \pm 6\end{array}$ & $\begin{array}{l}\text { Chernobyl } \\
\text { Chernobyl }\end{array}$ \\
\hline
\end{tabular}

\footnotetext{
*Not detected when first value is less than the two-standard-deviation error of counting (second value).
} 
TABLE 3 (CONCLUDED)

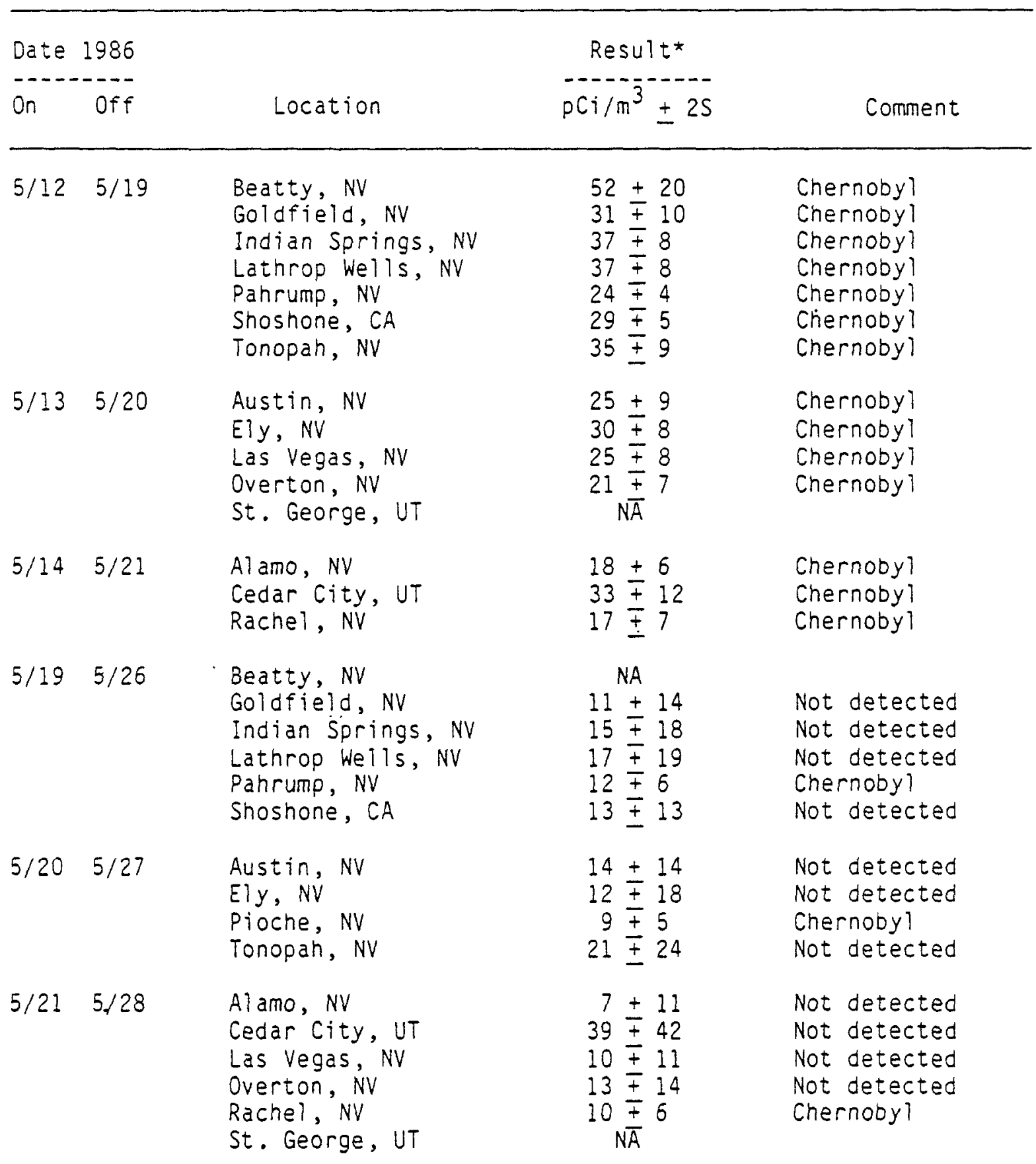

\footnotetext{
*Not detected when first value is less than the two-standard-deviation error of counting (second value):
} 


\section{SECTION XI}

REENTRY

Reentry Mining and Observations

Recorder and Oscilloscope Sealed Environmental System (ROSES) Area

Mining to recover experiments and data began on May 31, 1986. Figure 10 is a map showing the reentry mining routes. Numbers in brackets on the map match those inserted in this text for reference to location. The first reentry drift [1], U12t.08, was driven from the U12t.07 drift with a $5.5 \%$ upgrade. On June 5 , an opening was made by means of a crosscut drift into an existing alcove on the WP side of the U12t.02 cable DPP [2]. A reentry team entered the alcove and proceeded into the U12t.02 bypass drift, where a radiation reading indicated a level of $8 \mathrm{R} / \mathrm{h}$. The team returned to the reentry drift after staying less than five minutes in the radiation area. The average exposure was 600 $\mathrm{mrem} / p e r s o n$. A bulkhead was installed in this crosscut drift and shotcrete was applied to shield the reentry drift from radiation.

Reentry mining continued toward a point above the U12t.01 main drift [3]. Mining operations were terminated in this area on June 17 when weak rock and radiation were encountered. This drift was abandoned and a shotcreted barrier was constructed to shield against radiation. Mining of the reentry drift then continued toward the crosscut drift between the U12t.01 HLOS drift and the ROSES alcove and was stopped 10 feet short of that point [4]. Probe holes were drilled into the crosscut drift and readings of $1 \mathrm{R} / \mathrm{h}$ and less were obtained. A probe hole from the reentry drift into the ROSES alcove was completed on June 24. The radiation level inside the ROSES alcove was $2.5 \mathrm{R} / \mathrm{h}$.

A drift was mined from the reentry drift at a downgrade to intersect the ROSES alcove [5]. This drift was stopped 5 feet short of the alcove and three holes were drilled from the face of the drift into the alcove. A radiation reading taken 1 foot into the alcove iridicated $1 \mathrm{R} / \mathrm{h}$. A video camera was inserted into the alcove. One ROSES was observed on each side of the camera. Cable trays, cables, and water lines were also seen. Structurally, the alcove appeared to be in good condition.

In an effort to obtain data from four SNL Digital Acquisition and Analysis System (DAASY) ROSES, a 4-foot by 6-foot opening was mined into the alcove on September 23, 1986. A visual examination made through this opening indicated a gray-to-black coating on all equipment. The sides of one ROSES were bowed inward. On September 25, a four-man damage assessment team entered the ROSES alcove. The invert (floor) was covered with a 1 -inch-thick layer of dry powdery material, 


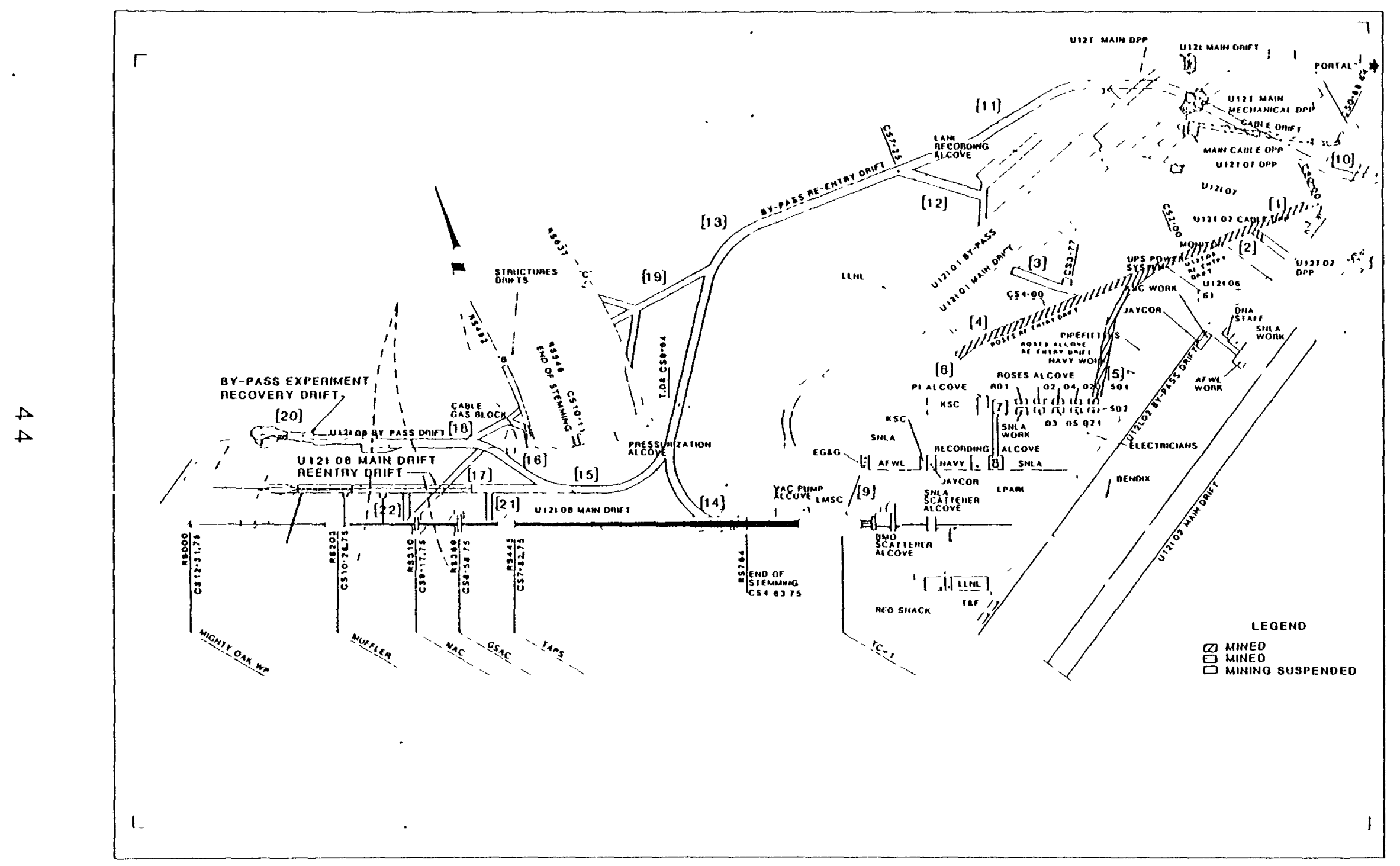

Figure 10. U121.08 Tunnel Reentry Map 
and insulation on cables was melted. One SNL ROSES door was opened and the equipment inside appeared to have been exposed to high temperatures. The team made its way to the U12t.02 bypass drift. The depth of the ash-type dust on the invert and the increased radiation levels approached $11 \mathrm{R} / \mathrm{h}$ (about 6 inches above the invert). When the communications line got caught, the team was forced to return without reaching the U12t.02 bypass drift. The doors to the other 3 SNL DAASY ROSES could not be reached and holes were cut through one side of each ROSES to examine the internal conditions. The ROSES were no longer sealed (tunnel air was inside), the equipment had a burned appearance, and ash-type dust was found. The team returned to the reentry drift. Radiation exposures ranged from 900 to $1270 \mathrm{mrem}$. On October 8 and 9 , teams entered the ROSES drift and cut holes in each side of each of the four ROSES (ranging in size from $3 \mathrm{ft}$ by 4 ft to 6 feet square) to a Tlow room for data and equipment recovery. Individual radiation exposures ranged from 90 mrem to a maximum of 915 mrem. On October 14 , SNL personnel entered the ROSES and recovered several computer disk drives and one power supply. On october 21 , 1986, a reentry team entered the U12t.02 bypass drift and noted that gas sampling lines were broken, and missing in some areas. The team reached the recording alcove and found rubble blocking the entrance.

In early March 1987, a reentry drift was mined into the pretest crosscut drift connecting the ROSES alcove and the U12t.01 main drift [6]. A radiation reading inside this crosscut indicated $40 \mathrm{mR} / \mathrm{h}$. A quartz light beam into the crosscut revealed a dark gray coating on the ribs, no signs of damage toward the ROSES drift, and a large muck (rubble) pile near the intersection with the U12t.01 bypass drift. A reentry into the recording alcove was conducted on March 31 . A team entered the ROSES reentry drift through a pretest crosscut connecting the U12t.01 main drift and the ROSES alcove. The team inspected the U12t.01 main drift and then moved back through the crosscut to the ROSES alcove. The crosscut was in excellent condition, but insulation on cables had melted and copper wire was seen. The ROSES alcove appeared to have been exposed to high temperatures. Maximum radiation reading in the alcove was $300 \mathrm{mR} / \mathrm{h}$. The team viewed the first recording alcove [7] and proceeded through a crosscut drift into the recording alcove. This crosscut drift was in good condition. Cable racks were tipped over and some cables and a layer of dust were on the invert. Cable insulation was mainly intact. When the team reached the recording alcove [8], the ground conditions were good; however, most of the instrumentation racks were in a massive pile. There was about 2 inches of dust on the invert and the radiation reading nearby was $2 \mathrm{R} / \mathrm{h}$. The team continued toward the crosscut to the scatterer alcoves. There was a lot of rubbie in this area and many cables were completely burned. The high-temperature gases appeared to have flowed from the scatterer alcoves into the recording alcove. The crosscut going into the Kaman Sciences Corporation (KSC) alcove was filled with rubole. In the crosscut to the test chamber area, the liner in the crosscut drift plug had been blown out but the plug was intact [9]. One test chamber door was found 8-to-10 feet from the HLOS pipe in the crosscut. About one-half of the feedthrough ports on the test chamber had been blown out. The shield wall on the portal side of the test chamber was relatively intact. Test chamber pipe supports were also 
intact. After checking conditions in the test chamber area and the scatterer stations, the team returned to the fresh air station. This reentry lasted one hour.

\section{Bypass Area}

On June 20, 1986, the second major reentry drift was started from the vicinity of the U12t.02 bypass drift and the T tunnel cabie orift [10]. The initial drift was mined on a 7\% upgrade to cross over the cable DPP, the U12t.01 main drift mechanical DDP, and the open U12t.01 bypass drift. The heading was then turned to travel approximately parallel to the LANL recording alcove [11]. The drift was mined at a downgrade until the invert level was approximately the same as the level of the U12t.01 bypass drift. A probe hole was drilled into the LANL alcove and a Radsafe probe into the alcove read $90 \mathrm{mR} / \mathrm{h}$ and a temperature of $65^{\circ} \mathrm{F}$. A crosscut drift was mined from the bypass reentry drift toward the LANL recording alcove, reaching that alcove on July 30 [12]. Upon entry, the LANL recording alcove appeared in good physical condition; however, there was evidence of exposure to high temperatures. Insulation on cables had melted, as had the plastic on a telephone. Radiation readings ranged from $45 \mathrm{mR} / \mathrm{h}$ to 200 $m R / h$. Two recovery teams entered the recording alcove and recovered data films and computer memories. Upon disassembly, memory units were found to be damaged and efforts to decontaminate the units to acceptable levels were not successful. The alcove was secured and mining of the bypass reentry drift continued [13].

The heading of the bypass reentry drift was turned southward to pass. over the U12t.08 bypass drift, close to the pressurization alcove. The drift continued to a point close to, but higher than, the U12t.08 HLOS pipe (main) drift [14]. A hole was mined downward and to the right, exposing the HLOS pipe. A hole was cut into the pipe and Radsafe personnel inserted a probe and recorded radiation readings ranging from 2.5 to $8 \mathrm{R} / \mathrm{h}$. A 24 -inch square hole was cut into the pipe and a video camera and lights were inserted on September 9 and 10. The video camera revealed that the stiffener rings inside the pipe were bent toward the portal and pieces of the rings were missing. The hole in the pipe was covered with lead shielding, and the area was secured.

Mining continued parallel to the U12t.08 main drift [15]. A right turn was made to intersect the U12t.08 bypass drift on the WP side of the cable gas block area, in the vicinity of the MAC crosscut drift [16]. This point was reached on September 22. A hole was orilled into the face of the U12t.08 main drift reentry drift [17] parallel to the Ul2t.08 main drift toward the working point. Mining of the U12t.08 main drift reentry drift continued. Four holes were drilled into the left rib of the main drift reentry drift to intersect the HLOS pipe drift between the TAPS and GSAC locations. No pieces of HLOS pipe were encountered in any of these drill holes. Also, three holes were drilled into the left rib of the main drift reentry drift across the HLOS pipe drift at a point on the WP side of the MAC location. The highest radiation reading in any of these holes was 140 $\mathrm{mR} / \mathrm{h}$. 
Mining continued in the U12t.08 main drift reentry drift between the MAC and muffler locations. Mining was stopped on September 30 to recover several experiments. Reentry mining continued in the U12t.08 bypass drift, and several experiments were recovered. Mining in this drift was stopped on October 23 and mining toward the "B" structures drift commenced on October 24 [18]. "B" drift was reached on November 6. Some experiments were recovered. Radiation levels were background. Mining from the bypass drift into " $C$ " structures arift was started on October 29 [19]. A hole was drilled into " $\mathrm{C}$ " drift, and a radiation reading of $4.5 \mathrm{mR} / \mathrm{h}$ was recorded. Mining continued and the " $C$ " structures drift was reached on November 3 . A radiation measurement indicated $30 \mathrm{mR} / \mathrm{h}$. Some experiments were recovered, and the area was secured.

In early November, probe holes were drilled from the face of the U12t.08 main drift reentry drift toward the working point. Radiation readings in these holes ranged from background to a high of $4.5 \mathrm{R} / \mathrm{h}$. Mining in the U12t.08 bypass reentry drift continued in late November and was stopped on December 2 [20] to drill six probe holes from the face. Radiation readings ranged from background to $1 \mathrm{R} / \mathrm{h}$.

No reentry work was accomplished during the Christmas-New Year hol iday period. Most of the reentry work in January and February 1987 consisted of experimenters recovering data from " $B$ " and " $C$ " drifts.

On March 12, 1987, mining commenced on a crosscut drift from the U12t.08 main drift reentry drift toward the U12t.08 main (HLOS) drift to intersect the HLOS drift on the WP side of the TAPS [21]. The HLOS drift was reached on March 24. Radsafe measurements indicated 0.5 $\mathrm{mR} / \mathrm{h}$ on the invert and $50 \mathrm{mR} / \mathrm{h}$ near the center of the HLOS drift. No explosive and toxic gases were discovered. Initial observations from the mouth of the crosscut revealed that the HLOS pipe was missing from an area between 402 and $410 \mathrm{ft}$ from the WP and that the pretest bulxhead at $404 \mathrm{ft}$ had been ripped from the ribs of the HLOS drift, exposing tuff on the ribs. The HLOS pipe was open. Each section of plpe between stiffener rings had pulled off the WP side ring and was folded down and back toward the portal. Looking toward the portal, the TAPS housing was visible, and the door had closed. The area was secured.

A reentry team entered the HLOS pipe on March 25. The TAPS door had closed but the center part of the door (approximately a 6-footdiameter circle) was gone. The TAPS housing was not severely damaged. The reentry team proceeded through the holes toward the test chamber. The HLOS pipe on the portal side of the TAPS was torn and wrinkied in places but basically intact. A 20-foot-long section of the HLOS pipe at the end of stemming was missing. The tunnel at the end of stemming appeared intact and was in good condition. There was a considerable amount of debris in and about the test chamber. The reentry team then returned through the TAPS and proceeded to the WP side of the access crosscut. The GSAC doors were gone, except for pieces inside the housing. The HLOS pipe was missing on the WP side of the GSAC and a small pile of muck was on the invert. The MAC doors were missing, but the housing was in place. A large muck pile was on the WP side of the MAC. 
Mining of a crosscut drift from the U12t.08 main drift reentry drift into the main HLOS pipe drift at a point on the WP side of the MAC commenced on March 27. On April 7, a probe hole was drilled into the HLOS drift. Radiation readings were near background. The crosscut drift was opened into the HLOS drift on April 9 [22]. A large amount of tuff had fallen away from rock bolts in the back and onto the invert of the HLOS drift. Radiation readings in the HLOS drift ranged from 40 to $50 \mathrm{mR} / \mathrm{h}$. Poor ground conditions prevented further examination of this area.

Further reentry work will be very limited and will consist primarily of recovering some remaining experiments, drilling random probe holes, and a small amount of additional mining. In general, the information required has been gathered.

\section{Experiments/Data Recovery and Equipment Loss}

Extensive reentry efforts have resulted in the recovery or examination of all passive experiments located in the U12t.08 bypass drift, the MAC crosscut drift, and the " $B$ " and " $C$ " structure drifts. In addition, manned reentry has also been made in the LANL hardened alcove, ROSES alcove, and the recording alcove. The equipment in these areas did not survive the hostile posttest environment, and most was lost. SNL has managed to salvage some data stored on hard disks in the ROSES alcove and will continue to retrieve that data as time and manpower allow.

It is now known that some of the experiments, all of the diagnostic equipment, and much of the construction equipment in the tunnel complex were lost as a result of heat damage and radiation contamination. At present, the loss of normally recoverable and reusable equipment is reported at approximately 32 million dollars. In spite of these equipment losses, much of the expected data from the experiments was recovered. It was telemetered to recording instruments outside the tunnel complex before the destructive environment within the complex occurred. 
SECTION XII

CONCLUSIONS

Based upon the data and information in this report there are several conclusions which may be drawn:

- No radiation associated with the dynamic phase of the MIGHTY OAK test was released to the atmosphere.

- As a result of routine controlled tunnel purging, the maximum dose any off-site person could have received for the entire period of purging would have been insignificant.

- There were no radiation exposures in excess of permissibie guidelines for radiation workers or off-site residents, and no injuries occurred in connection with the execution of the test.

- Much of the expected data was recovered.

- Normally recoverable and reusable equipment with a value of approximately 32 million dollars was lost.

This report does not cover possible or probable causes for the loss of experiment, diagnostic, or construction equipment within the tunnel complex. It is intended only to be an accounting of events which took place relative to the MIGHTY OAK test. 


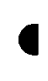

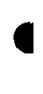




\section{GLOSSARY}

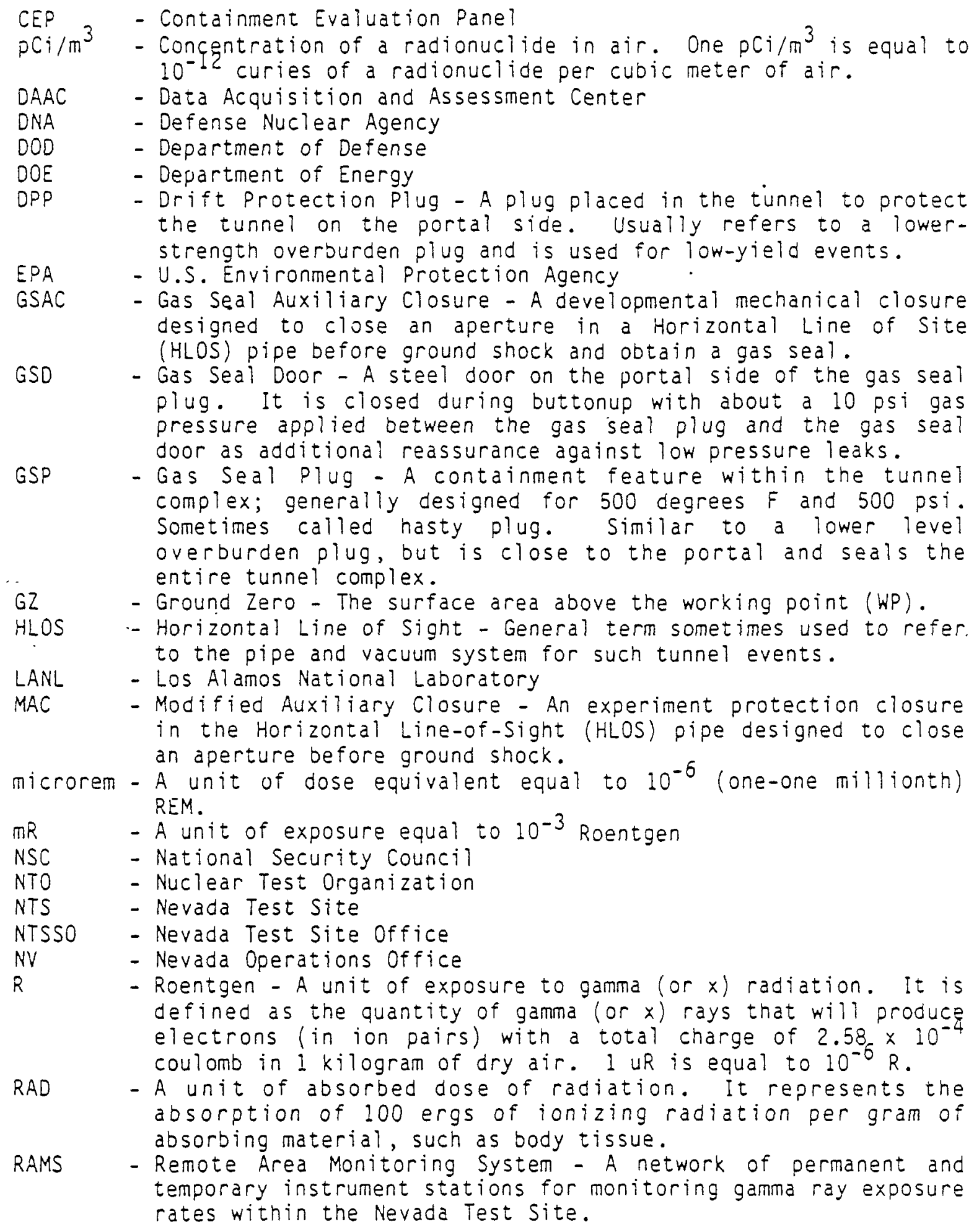




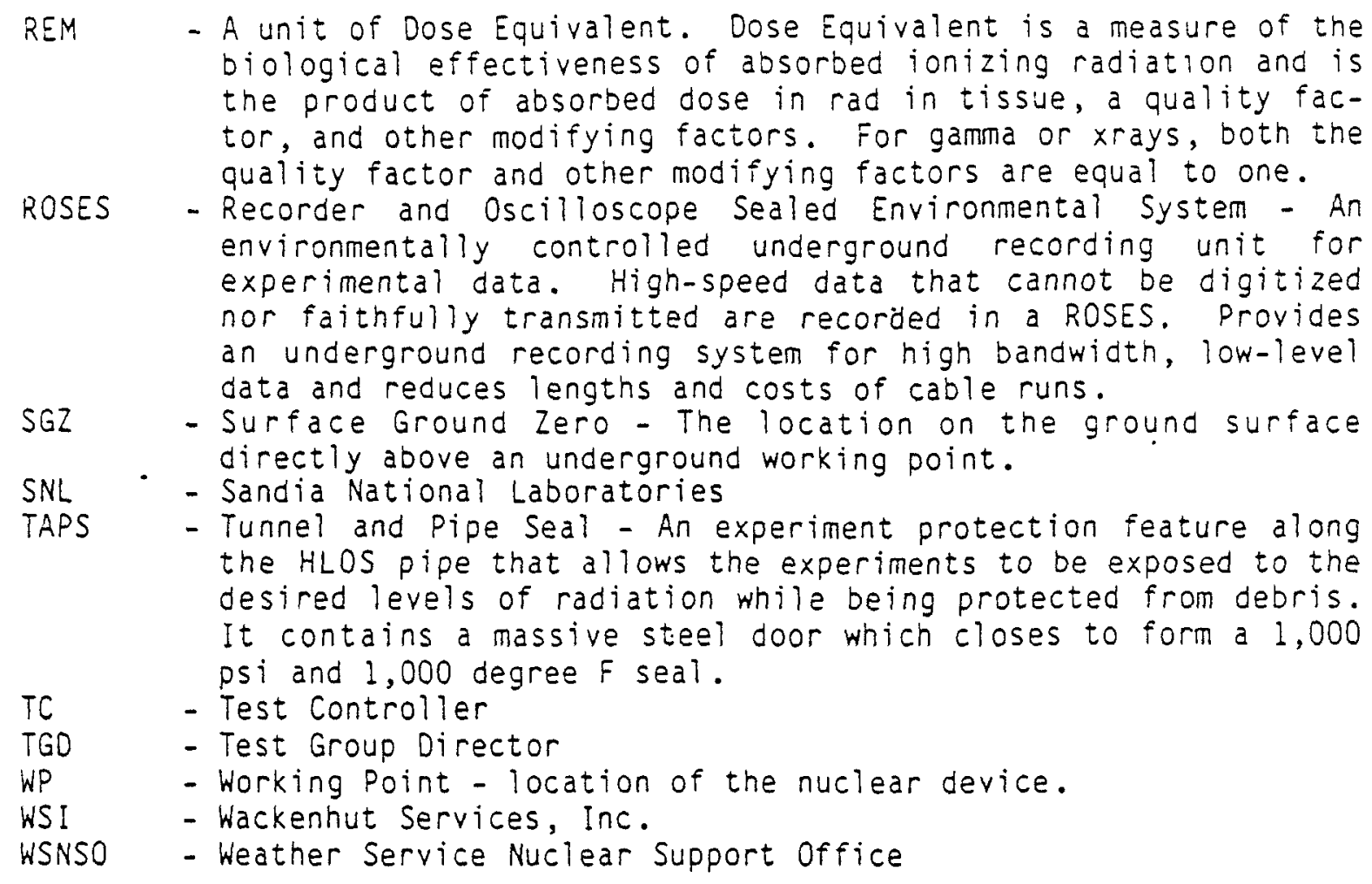

